\title{
The Switchgrass Microbiome: A Review of Structure, Function, and Taxonomic Distribution
}

\author{
Rachel Hestrin, ${ }^{1, \dagger}$ Marissa R. Lee, ${ }^{2}$ Briana K. Whitaker, ${ }^{2}$ and Jennifer Pett-Ridge ${ }^{1}$ \\ ${ }^{1}$ Physical and Life Sciences Directorate, Lawrence Livermore National Laboratory, Livermore, CA 94550, U.S.A. \\ ${ }^{2}$ Department of Plant and Microbial Biology, North Carolina State University, Raleigh, NC 27607, U.S.A.
}

Accepted for publication 29 September 2020.

\section{ABSTRACT}

Switchgrass (Panicum virgatum L.) has been championed as a promising bioenergy crop due to its high productivity across a wide environmental range. The switchgrass microbiome-including bacteria, archaea, fungi, and other microbiota inhabiting soil and plant tissues-can influence plant function substantially. We conducted a review of the literature investigating switchgrass microbiome structure, key functional roles, and taxa isolated from field-grown plants. Although site conditions and plant compartment (i.e., location within shoots, roots, or root-influenced soil) appear to be the strongest drivers of switchgrass microbiome structure, the microbiome is also shaped by climate, season, and host genotype. Studies comparing across plant species show that the switchgrass microbiome is more similar to the microbiomes of other perennial plants than to the microbiomes of annual plants. Members of the switchgrass microbiome confer several benefits to their host. Most notably, mycorrhizal fungi can increase plant biomass many-fold, associative nitrogen-fixing bacteria can provide a substantial portion of the plant's nitrogen demand, and fungal endophytes can improve plant tolerance to drought. Although the fungi and bacteria cultured from switchgrass represent only a portion of the microbiome, these serve as a valuable resource for researchers interested in investigating functional outcomes of the switchgrass microbiome. We highlight areas where additional research is necessary for a more comprehensive understanding of switchgrass microbiome structure, function, and potential to enhance sustainable bioenergy production. Key gaps include the role of understudied organisms (e.g., viruses, microeukaryotes, and nonmycorrhizal fungi), multitrophic relationships, mechanisms underpinning switchgrass-microbiome interactions, and fieldscale validation of experimental findings.

Keywords: agriculture, bacteria, bioenergy, biofuel, endophyte, fungi, genomics, microbiome, mutualism, mycorrhizae, nutrient cycling, Panicum virgatum, perennial crop, plant-microbe interactions, plants, rhizosphere and phyllosphere, soil ecology, yield and crop productivity
${ }^{\dagger}$ Corresponding author: R. Hestrin; hestrin1@llnl.gov

Author contributions: R.H. and M.L. conducted the literature search synthesis and data collection. B.W. analyzed taxonomic information from culture-based studies. R.H., M.L., and B.W. wrote the manuscript with input from J.P.R.

Funding: This research is based upon work supported by the U.S. Department of Energy (DOE), Office of Biological and Environmental Research, Genomic Sciences Program, Bioenergy Scientific Focus Area SCW1039 and Sustainable Biofuels Program award SCW 1555 at Lawrence Livermore National Laboratory (LLNL). Work at LLNL was conducted under the auspices of DOE Contract DE-AC52$07 \mathrm{NA} 27344$.

*The $e$-Xtra logo stands for "electronic extra" and indicates that one supplementary figure and two supplementary tables are published online.

The author(s) declare no conflict of interest.

This article is in the public domain and not copyrightable. It may be freely reprinted with customary crediting of the source. The American Phytopathological Society, 2021.
Switchgrass (Panicum virgatum L.) has been identified as one of the most promising bioenergy crops in the United States, with the potential to provide high-yielding biomass on marginal soils that are otherwise unsuitable for traditional agricultural row crops (Gelfand et al. 2013; McLaughlin and Kszos 2005). Due to its broad geographic adaptation, perennial life cycle, and broad tolerance to pathogens and abiotic stress (e.g., water and nutrient limitation), as well as tissue quality for fuel conversion, switchgrass has been championed as a sustainable and versatile cellulosic feedstock (Liebig et al. 2008). Additionally, switchgrass cultivation may enhance biodiversity and provide a suite of ecosystem services such as increased water quality, pest suppression, and soil carbon storage through its deep root system (Werling et al. 2014). Native to much of North America, phenotypic and genotypic variation across switchgrass's geographic range is the result of periodic glaciation events, which led to alternatively high gene flow and population 
isolation (Zalapa et al. 2011; Zhang et al. 2011). Upland ecotypes (e.g., Blackwell, Cave-in-Rock, and Summer) are often found in xeric to mesic regions, are shorter with higher tiller production, and are most commonly octoploid. Lowland ecotypes (e.g., Alamo and Kanlow) are typically found in hydric zones, are taller with fewer tillers, and are commonly tetraploid (Lowry et al. 2014; Zhang et al. 2011). The significant genetic diversity of switchgrass has provided opportunities for breeding and the release of new lines for improved biomass yields (Casler 2012).

In addition to substantial research on switchgrass phenotypic and genotypic variation, a growing body of literature has investigated interactions between switchgrass and its microbiome. Like most plant-associated microbiomes, the switchgrass microbiome contains an assortment of biota including viruses, bacteria, archaea, fungi, and microeukaryotes. Interactions between these organisms and the host plant are complex and varied, ranging from beneficial to antagonistic (Kleczewski et al. 2012; Vacher et al. 2016). In switchgrass production systems, informed management of mutualistic plant-microbe interactions could increase yields (Brejda et al. 1998; Kim et al. 2012; Ray et al. 2015), improve nutrient acquisition and stress tolerance (Clark et al. 2005; Ghimire and Craven 2011; Giauque et al. 2019; Ker et al. 2014; Wang et al. 2016), and provide ecosystem services such as carbon sequestration (McLaughlin and Kszos 2005; Sher et al. 2020; Slessarev et al. 2020) and enhanced soil biodiversity (Emery et al. 2017; He et al. 2017). To simultaneously maximize the economic feasibility of switchgrass as a bioenergy feedstock and as an ecological restoration agent capable of significant soil conservation and climate mitigation, it is important to understand switchgrass-microbiome interactions in both replete and stressful growing conditions. In addition, switchgrass's extensive genotypic and phenotypic variation renders a comprehensive understanding of the switchgrass microbiome's structure and function both challenging and useful. Such an understanding will facilitate investigations of mechanisms driving plant-microbe interactions in different environments, broader predictions of plant and microbial response to global change, and management of more productive and resilient bioenergy systems.

We conducted a systematic review of the literature on switchgrassmicrobiome interactions and identified three core themes, which we focus on here. First, we summarize drivers of switchgrass microbiome taxonomic structure, which we define as the combination of microbial community composition and abundance of individual members. Second, we discuss the key functional roles of the switchgrass microbiome and highlight areas where more research is needed. Third, we describe the taxonomic distribution of fungi and bacteria isolated into culture from field-grown switchgrass plants and discuss their potential applications for inoculant development and switchgrass microbiome research. For the purpose of this review, we limited our definition of the microbiome to above- and belowground epiphytes (organisms found living on the outside of plant tissues) and endophytes (organisms found living within plant tissues), and microorganisms found in plant-influenced soil (including both rhizosphere soil and bulk soil from switchgrass-dominated systems; hereafter, we refer to these as "root-influenced" or "switchgrassinfluenced" soil). Although we include some discussion of viruses and microeukaryotes, we found relatively few articles about mutualistic interactions between switchgrass and these organisms; thus, we excluded them from our quantitative summaries and focused primarily on switchgrass-associated bacterial, archaeal, and fungal organisms, which are relatively better characterized. We also excluded studies that focused solely on plant pests and pathogens.

\section{SYSTEMATIC REVIEW OF SWITCHGRASS MICROBIOME LITERATURE}

We performed a search on the Web of Science (12 May 2020) to gather research articles that characterized or manipulated microbial communities associated with living switchgrass plants. Our search identified articles that included a combination of "switchgrass" or "Panicum virgatum" and at least one search term associated with microbiota, including "microb*", "microorg*", "bact*", "fung*", "fauna", "invertebrate", "protist", "ciliate", "nematode", "virus", "viral", "collembola", "mites", "protozoa", "annelid", or "stramenopile". In total, we identified 607 articles published between 1993 and 2020 using these search parameters. We included an additional three articles because they were either referenced directly in one of the articles resulting from our Web of Science query or were otherwise brought to our attention. Of the 610 articles identified, 392 were immediately excluded from further review because they did not discuss microbiota associated with living switchgrass plants (e.g., studies focused on the decomposition of switchgrass biomass for bioenergy conversion). Of the remaining 218 articles, an additional 116 were excluded based on a lack of information about bacterial, archaeal, or fungal community structure or function. Many of the articles that we excluded reported on processes relevant to the switchgrass microbiome such as greenhouse gas emission or soil nutrient cycling but did not identify microbial taxa putatively responsible for these processes. Few articles reported on communities of nonpest or nonpathogenic viruses and microeukaryotes. Thus, we chose to exclude these organisms and associated articles from our numerical summaries (Figs. 1, 2, and 3; Table 1) but did consider their findings in our discussion. Articles that did not report original findings (e.g., review articles) were also excluded from our numerical summaries but still considered in our discussion of dominant trends and information gaps. Of the remaining 102 articles, 55 focused solely on microbial community structure, 43 focused solely on microbial effects on plant function, and 4 investigated both structure and function (Table 1 and Supplementary Table S1). A flowchart depicting our article filtering procedure is shown in Supplementary Figure S1.

For the 102 remaining articles, we first classified each article based on whether it described (i) microbial community structure or (ii) plant functional response.

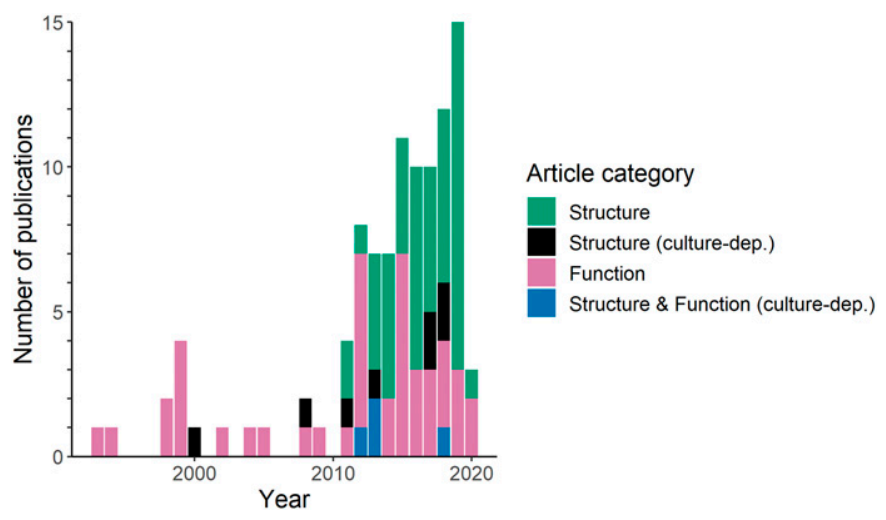

Fig. 1. Number of peer-reviewed publications focused on the (nonpest and nonpathogenic) microbiomes of switchgrass (Panicum virgatum L.) from 1990 to April 2020. Articles were classified by topic: "Structure" indicates articles about community composition and abundance, "Function" indicates articles that assessed plant functional response to specific microbial taxa or communities, and "culture-dep." indicates that a culture-dependent approach was used. All articles included can be found in Supplementary Table S1. 
For articles pertaining to microbial community structure, we recorded:

1. Community characterization method: description of whether the approach was culture-dependent or -independent.

2. Microorganisms assessed: classified as bacteria, archaea, fungi, or other, and whether the study focused on a particular functional group (i.e., mycorrhizal fungi or associative nitrogen $[\mathrm{N}]$-fixing bacteria).

3. Plant compartment assessed: classified into shoot (including seed, leaf, and stem), root (including both root endophytes and root epiphytes), or root-influenced soil. Root-influenced soil was used as a single category to group both rhizosphere and bulk soil collected from switchgrass-dominated systems due to inconsistencies in sampling methodology across studies.

4. Community structure predictor variables: description of variables used to explain variation in microbial community structure, including (i) plant-associated compartment, (ii) plant host identity (e.g., species or cultivar), (iii) site (e.g., environmental gradients underpinned by spatially structured sampling), (iv) time, and (v) fertilization treatment.

For articles pertaining to plant function, we recorded:

1. Microorganisms manipulated: classified as described above.

2. Addition or removal of microbes: classified by whether the microbiome was manipulated by adding or removing taxa (e.g., through fungicide or antibiotic application, autoclaving treatment, and so on). For studies that added microbial taxa, we recorded how many taxa were coinoculated.
3. Plant-associated compartment treated: classified as described above.

4. Interaction treatments: description of nonmicrobial treatments crossed with the microbial treatment, including (i) host identity and (ii) resource level (i.e., water and nutrient treatments).

5. Host growth setting: classified as growth chamber, greenhouse, or field.

6. Plant response variables: description of quantified plant responses including (i) growth and (ii) nutrient content.

Finally, due to their experimental tractability and potential as commercial inoculants, we recorded the taxonomic identity and abundance of microorganisms characterized using a culturedependent approach. Where possible, we downloaded raw supplementary data files. Otherwise, figures and tables reporting microbial abundance were manually curated (Supplementary Table S2). Because sufficient metadata were not available for 2 of the 10 studies describing cultured isolates (i.e., the microbial taxonomy or abundance information was not provided in a format that could be extracted for subsequent analysis), our summary of cultured organisms included a total of eight studies (Eom et al. 2000; GagneBourgue et al. 2013; Giauque and Hawkes 2013; Kleczewski et al. 2012; Luo et al. 2017; Whitaker et al. 2018; Xia et al. 2013, 2018). When not reported by authors, taxonomic groups above the level of genus were cross-referenced using Mycobank and the UNITE reference database (Nilsson et al. 2019; Robert et al. 2013). Due to differences in methodologies and reporting of microbial abundance across studies, we chose to summarize microbial taxonomy in a graphical representation based on the presence or absence of each

\begin{tabular}{|c|c|}
\hline \\
\hline & \\
\hline \multicolumn{2}{|c|}{$\begin{array}{l}\text { Shoot epiphytic and endophytic organisms } \\
\begin{array}{ll}\text { Microbial group } & \text { Taxa } \\
\text { Archaea* }^{*} & \text { no data }\end{array}\end{array}$} \\
\hline Bacteria: $\mathrm{N}$-fixing organisms ${ }^{*}$ & Proteobacteria (Burkholderiales and Rhizobiales) \\
\hline Bacteria: Other* & Actinobacteria, Bacteroidetes, Firmicutes, Proteobacteria \\
\hline Fungi $^{\star}$ & $\begin{array}{l}\text { Dothideomycetes, Eurotiomycetes, Saccharomyces, } \\
\text { and Sordariomycetes }\end{array}$ \\
\hline
\end{tabular}

\section{Root organisms}

Microbial group

Archaea*

Bacteria: N-fixing organisms ${ }^{\star}$ Proteobacteria (Burkholderiales and Rhizobiales)

Bacteria: Other

Fungi: Mycorrhizal fungi

Fungi: Other*

\section{Soil and rhizosphere organisms}

Microbial group Taxa

Archaea* Chrenarchaeota, Thaumarchaeota

Bacteria: N-fixing organisms* Proteobacteria

Bacteria: Other

Fungi: Mycorrhizal fungi

Fungi: Other

Microeukaryotes*
Acidobacteria, Actinobacteria, Bacteroidetes, Proteobacteria, and Verrucomicrobia Glomeromycetes

Agaricomycetes, Archaeorhizomycetes, Dothideomycetes, Mortierellomycetes, Pezizomycetes, Sordariomycetes, and Tremellomycetes

Alveolata, Amoebozoa, Nematoda, Metazoa, Rhizaria, and Stramenopiles
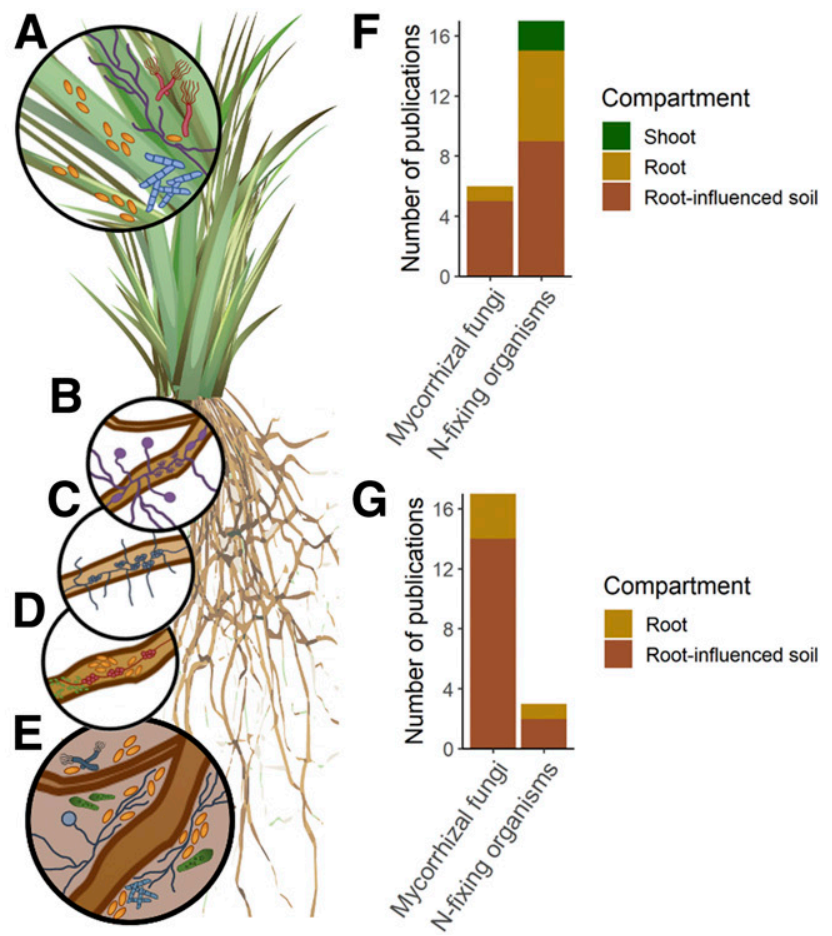

Compartment

Root

Root-influenced soil

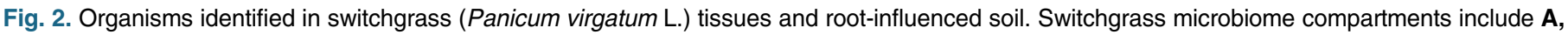
epiphytic and endophytic organisms inhabiting shoots and other aboveground tissues; organisms inhabiting root tissues such as B, arbuscular mycorrhizal fungi; C, sebacinoid fungi; and D, other root endophytes; and E, soil and rhizosphere organisms (drawings not to scale). Inset bar plots

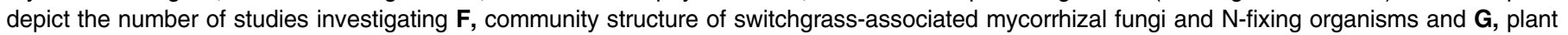
functional responses to these organisms in different plant and soil compartments. The inset table lists the most common taxa identified in the published literature, grouped according to plant-associated compartment. Very little information is currently available for several microbial groups. Microeukaryotes

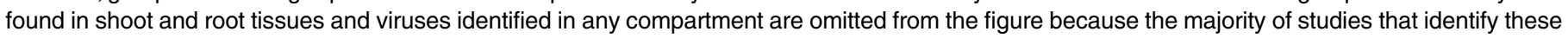
microbial groups in switchgrass systems focus on pests and pathogens, which are beyond the scope of this review. Organisms reported in fewer than 10 published studies are indicated with an asterisk. 

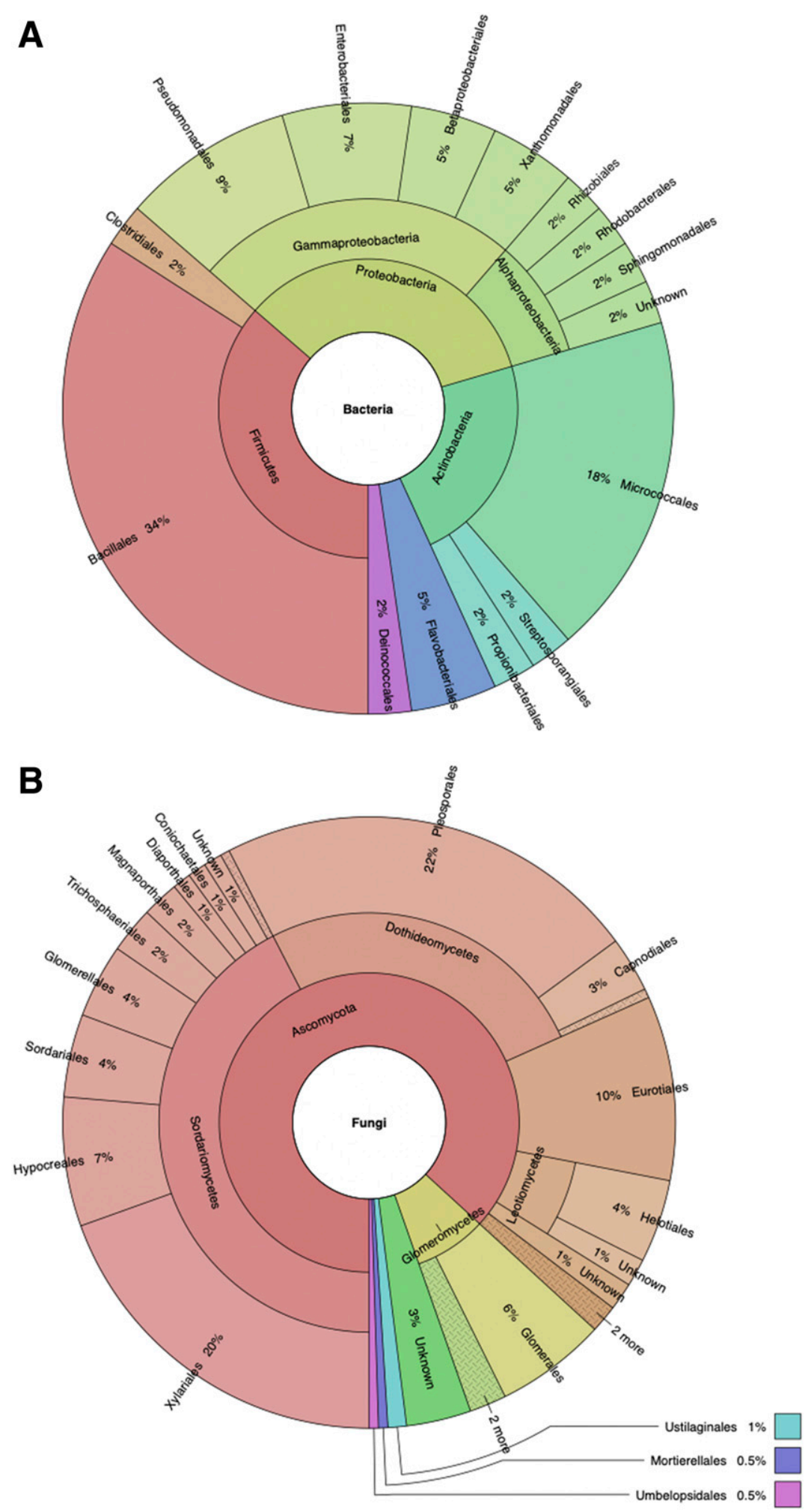

Fig. 3. Taxonomic breadth of bacteria and fungi isolated from switchgrass (Panicum virgatum L.) tissues. The percentage of $\mathbf{A}$, bacterial and $\mathbf{B}$, fungal isolates belonging to each taxonomic rank is shown from the rank of phylum (inner ring) to order (outer ring). Percentages were calculated by dividing the number of times that a specific strain was isolated across all eight studies by the total number of strains isolated within a taxonomic rank. Rank names not shown due to space constraints include Chaetosphaeriales ( $0.5 \%$ of the class Sordariomycetes), Dothideales $(0.5 \%$ of the class Dothideomycetes), Gigasporales (1\% of the class Glomeromycetes), and Diversisporales (1\% in the class Glomeromycetes). Studies referenced include Eom et al. (2000), Gagne-Bourgue et al. (2013), Giauque and Hawkes (2013), Kleczewski et al. (2012), Luo et al. (2017), Whitaker et al. (2018), and Xia et al. (2013, 2018). 
taxon (Ondov et al. 2011). Each culture was accounted for individually at the genus level, regardless of relative abundance. Multiple strains belonging to the same genus were accounted for separately. Thus, percentage summaries across higher taxonomic levels (e.g., phylum, class, and order) represent (i) the presence or absence of specific strains across the studies examined and (ii) the total number of strains isolated from that level. Percentages were calculated by dividing the number of times that a specific strain was isolated across all eight studies by the total number of strains isolated within a taxonomic rank.

\section{TRENDS IN SWITCHGRASS MICROBIOME RESEARCH}

The number of publications focused on switchgrass microbiomes has increased rapidly since 2011, reflecting growing interest, financial support, and technological capacity for research on bioenergy crops and plant-microbe interactions (Fig. 1). Of the 102 articles included in our synthesis, 59 reported on the community composition and abundance of switchgrass-associated microbial taxa (hereafter referred to as microbial "community structure"; see numerical summary in Table 1 and major findings in Table 2), 47 reported on switchgrass functional responses to microbial manipulations (see numerical summary in Table 1 and major findings in Table 3), while only 4 reported on both (Supplementary Figure S1; Moher et al. 2009), and 10 reported on the structure of microbial taxa isolated from switchgrass root and shoot tissues. Together,

TABLE 1

Numerical summary of studies describing switchgrass (Panicum virgatum L.) microbiomes

\begin{tabular}{|c|c|c|}
\hline \multirow[b]{2}{*}{ Study attribute } & \multicolumn{2}{|c|}{ Number of studies ${ }^{a}$} \\
\hline & Structure & Function \\
\hline \multicolumn{3}{|l|}{ Organism } \\
\hline Bacteria & 47 & 19 \\
\hline Fungi & 34 & 34 \\
\hline Bacteria and fungi & 22 & 6 \\
\hline Mycorrhizal fungi & 5 & 16 \\
\hline Nitrogen-fixing organisms & 11 & 6 \\
\hline Added microbes (versus removed) & * & 42 \\
\hline Added 1 microbe (versus many) & * & 31 \\
\hline \multicolumn{3}{|l|}{ Compartment } \\
\hline Shoot & 10 & 7 \\
\hline Root & 12 & 15 \\
\hline Root-influenced soil & 49 & 25 \\
\hline \multicolumn{3}{|l|}{ Environmental context } \\
\hline Manipulated resources & 17 & 16 \\
\hline Compared/manipulated host & 44 & 18 \\
\hline Compared sites & 21 & * \\
\hline Compared timepoints & 13 & * \\
\hline \multicolumn{3}{|l|}{ Plant response } \\
\hline Measured biomass & * & 36 \\
\hline Measured nutrient content & * & 13 \\
\hline Total & 59 & 47 \\
\hline
\end{tabular}

these studies describe switchgrass microbiome taxonomy, structure, and function across a wide array of conditions, including sandy to clay soils (Ker et al. 2012), xeric to mesic habitats (Whitaker et al. 2018), and fertilized monocultures to unmanaged mixed prairie systems (Revillini et al. 2019).

Approaches that have been used to investigate the switchgrass microbiome include amplicon sequencing, metagenomics, plant and microbial transcriptomics, metabolomics, biogeochemical analyses, and isolation of culturable microorganisms, as well as manipulations of environmental conditions, host genotype, and other factors in both greenhouse and field settings. The majority of studies characterizing the switchgrass microbiome (59 of the 102 studies included here) have documented the taxonomy or structure of switchgrass microbial communities grown in field or greenhouse settings. Of the studies that examined switchgrass functional responses (47 of the 102 studies included here), most assessed plant response to the addition of microbiota (42 studies) rather than to the suppression or omission of microbiota through chemical applications, steam sterilization, or physical separation (5 studies) (Table 1) (Brejda et al. 1998; Hartnett et al. 1994; Interrante et al. 2015; Johnson et al. 2008; Petipas and Bowsher et al. 2020). In addition, most studies assessed plant response to inoculation with only a single microbial taxon at a time (31 studies) (Table 1). Four of the five studies that suppressed or removed microbial taxa focused on fungi (Brejda et al. 1998; Hartnett et al. 1994; Interrante et al. 2015; Johnson et al. 2008). For those studies focusing on microbial community structure, a sizable fraction included experimental manipulation of resources (17 studies) (Table 1). Several studies used manipulations of both the microbial community and plant host type (18 studies) or soil resources (16 studies) such as soil moisture, $\mathrm{N}$, or phosphorus fertility (Table 1 ).

\section{DRIVERS OF SWITCHGRASS MICROBIOME TAXONOMY AND COMMUNITY STRUCTURE}

A better understanding of the forces that shape switchgrass microbiome structure may shed light on its function and potential applications in bioenergy production systems. Here, we highlight dominant drivers of the structure of switchgrass microbiome communities with putative benefits to plant function (Fig. 2A to G). We define microbiome "structure" as a combination of the composition of the microbial community and the abundance of its members.

Plant-associated compartment. Plant-associated compartments (shoots, roots, or root-influenced soil) provide habitats with different physical, chemical, and biological characteristics that shape microbial communities (Fig. 2) (Bulgarelli et al. 2012; Lundberg et al. 2012; Singer et al. 2019a). Of the 59 studies that investigate microbial community structure across these switchgrass compartments, most focus on comparisons between belowground compartments, including roots and root-influenced soil (which, in our definition, includes bulk soil) (Table 1). Fewer studies compare microbial communities between above- and belowground compartments (Table 1). Additionally, the wide variation in approaches and experimental designs can render cross-compartment comparison difficult. However, overall patterns suggest that the compositions of communities found in each compartment are distinct (Bahulikar et al. 2014; Roley et al. 2019; Singer et al. 2019a).

Most switchgrass microbiome studies that investigate community structure in different plant compartments examine bacterial and archaeal communities (Table 1). Bacterial phyla that are often found in high relative abundance across all switchgrass compartments include Actinobacteria, Bacteroidetes, and Proteobacteria (Chen et al. 2019; DeBruyn et al. 2017; Grady et al. 2019; Hargreaves et al. 2015; He et al. 2017; Liang et al. 2016; Mao et al. 2014; Revillini 
et al. 2019; Singer et al. 2019a,b). In switchgrass shoots, bacterial taxa from the phylum Firmicutes are common inhabitants (Bahulikar et al. 2014; Grady et al. 2019; Roley et al. 2019), while members of the phyla Acidobacteria and Verrucomicrobia are more commonly found in roots and root-influenced soil (Chen et al. 2019; DeBruyn et al. 2017; He et al. 2017; Liang et al. 2016; Mao et al. 2011, 2014; O'Brien et al. 2016; Revillini et al. 2019). Archaeal taxa identified in switchgrass roots and root-influenced soil include members of the phyla Chrenarchaeota and Thaumarchaeota (Bertagnolli et al. 2015; Mao et al. 2011; Meinhardt et al. 2018; Revillini et al. 2019; Singer et al. 2019a), though some 16S ribosomal RNA primer sets are not optimized to capture archaeal diversity or abundance (Fischer et al. 2016).

A small but growing body of work investigates the structure of switchgrass-associated fungal communities in different plant compartments. Several studies focus specifically on mycorrhizal fungi (i.e., arbuscular mycorrhizal fungi [AMF] and sebacinoid fungi) present in roots or root-influenced soil, although sequencing, culturing, and microscopy efforts suggest that mycorrhizal fungi make up a small portion of switchgrass microbiome taxa overall (Emery et al. 2018; Ghimire et al. 2011, 2009; Revillini et al. 2019; Singer et al. 2019a). Dominant mycorrhizal genera sequenced from roots and root-influenced soil include Glomus, Rhizophagus, and Septoglomus (Brodsky et al. 2019; Emery et al. 2018; Revillini et al. 2019). Although some studies use methods to target mycorrhizal fungi specifically, most fungal culturing methods and amplicon primer sets used for fungal community profiling are designed for whole-fungal-community analysis and are not optimized for mycorrhizal fungi. Therefore, studies employing these methods may underreport the abundance and diversity of this group (Řezáčová et al. 2016). The few culture-independent studies to investigate nonmycorrhizal fungal communities found species of Dothideomycetes and Sordariomycetes in high relative abundance in switchgrass roots (Singer et al. 2019a) whereas, in switchgrass-influenced soil, members of the classes Agaricomycetes, Archaeorhizomycetes, Dothideomycetes, Mortierellomycetes, Pezizomycetes, Sordariomycetes, and Tremellomycetes predominate (Brodsky et al. 2019; Rodrigues et al. 2017; Sawyer et al. 2019; Singer et al. 2019a). To date, no culture-independent studies describe fungal communities inhabiting switchgrass shoot tissues.

We assessed overall trends in bacterial and archaeal community structure across plant and plant-associated compartments (relatively few fungal studies assessed multiple compartments at once). These studies show that microbial community richness progressively decreases from soil to roots to shoots (Bahulikar et al. 2014; Grady et al. 2019; Roley et al. 2019; Singer et al. 2019a). Similar microbial diversity patterns have also been observed in plant-associated compartments of maize, Miscanthus, and Arabidopsis (Bodenhausen et al. 2013; Grady et al. 2019; Roesch et al. 2008) and have been linked to stronger selective pressures in plant tissues relative to soil, which may provide a wider array of ecological niches (Grady et al. 2019; Singer et al. 2019a). In addition to providing habitat for diverse organisms, soil is also an important source of bacterial colonizers for plant tissues (Grady et al. 2019).

Plant host genotype and phenotype. Plant genotypic and phenotypic traits can shape the structure of the microbial community associated with plant shoots, roots, and root-influenced soils (Jones et al. 2019; Li et al. 2018). Several studies show that switchgrass-associated microbial communities are significantly different from those associated with other bioenergy crops such as Miscanthus (Miscanthus $\times$ giganteus) and maize (Zea mays) (Emery et al. 2017; Grady et al. 2019; Jesus et al. 2016; Liang et al. 2015; Orr et al. 2015; Soman et al. 2018; Xue et al. 2019; Zhang et al. 2017) (Table 1, "Compared/manipulated host"). Due to the variety of approaches and experimental systems used to compare the microbiomes associated with switchgrass and other plant species, it is difficult to definitively identify taxa or characteristics that are unique to the switchgrass microbiome. However, interspecies

TABLE 2

Major findings related to drivers of switchgrass (Panicum virgatum L.) microbiome community structure

\begin{tabular}{|c|c|}
\hline Driver, major finding & Reference \\
\hline $\begin{array}{l}\text { Microbiome community structure is distinct in different plant } \\
\text { compartments; community richness progressively decreases } \\
\text { from soil to roots to shoots }\end{array}$ & $\begin{array}{l}\text { Bahulikar et al. 2014; Grady et al. 2019; Roley et al. 2019; Singer et al. } \\
\text { 2019a }\end{array}$ \\
\hline Soil serves as a reservoir for phyllosphere bacteria & Grady et al. 2019 \\
\hline Soil serves as a reservoir for root-associated bacteria & Singer et al. $2019 a$ \\
\hline $\begin{array}{l}\text { Switchgrass microbiomes differ significantly from those of other } \\
\text { bioenergy crops and are more similar to those of perennial crops } \\
\text { than to those of annual crops }\end{array}$ & $\begin{array}{l}\text { Orr et al. 2015; Liang et al. 2015; Jesus et al. 2016; Emery et al. 2017; } \\
\text { Zhang et al. 2017; Soman et al. 2018; Xue et al. 2019; Grady et al. } \\
2019\end{array}$ \\
\hline \multicolumn{2}{|l|}{ Site } \\
\hline $\begin{array}{l}\text { Edaphic conditions often explain more variation in microbial } \\
\text { communities than plant genotype or plant species composition }\end{array}$ & $\begin{array}{l}\text { Mao et al. 2011, 2013; Giauque and Hawkes 2013; Hargreaves et al. } \\
\text { 2015; Jesus et al. 2016; Soman et al. 2018; Whitaker et al. 2018; } \\
\text { Brodsky et al. } 2019\end{array}$ \\
\hline \multicolumn{2}{|l|}{ Climate } \\
\hline \multicolumn{2}{|l|}{ Management } \\
\hline $\begin{array}{l}\text { Nitrogen fertilization reduces soil microbial biomass, arbuscular } \\
\text { mycorrhizal fungi abundance, and nifH abundance in } \\
\text { switchgrass systems }\end{array}$ & $\begin{array}{l}\text { Oates et al. 2016; Jach-Smith and Jackson 2018, 2020; Revillini et al. } \\
2019\end{array}$ \\
\hline $\begin{array}{l}\text { Nitrogen fertilization does not affect switchgrass phyllosphere } \\
\text { bacterial and archaeal composition }\end{array}$ & Grady et al. 2019 \\
\hline
\end{tabular}


comparisons suggest that the switchgrass microbiome is more similar to microbiomes associated with perennial plants than those associated with annual plants. Management of perennial crops often involves reduced-tillage regimes, which can alter soil physical and chemical properties as well as microbial activity and community structure (Kraut-Cohen et al. 2020). Soil bacterial communities associated with switchgrass and Miscanthus spp. are more similar to each other than to those associated with maize, and have greater species richness and evenness (Zhang et al. 2017) and a greater abundance of $\mathrm{N}$-fixing organisms (Mao et al. 2013) relative to the maize soil microbiome. Organisms involved in $\mathrm{N}$ cycling (including ammonia oxidizers, diazotrophs, and denitrifiers) increase in abundance and diversity under cultivation of the perennial bioenergy grasses switchgrass and Miscanthus spp. (Mao et al. 2013). Fungal communities associated with switchgrass are also more similar to those associated with both Miscanthus spp. and big bluestem than to those associated with maize (Orr et al. 2015; Xue et al. 2019). In a study of 10 different bioenergy cropping systems, indicator taxa associated with switchgrass and Miscanthus spp. included Sphingobacterium and Novosphingobium spp. (Zhang et al. 2017). Both taxa can degrade lignin and may be enriched during switchgrass cultivation due to the build up of plant-derived organic matter under this deep-rooted perennial crop. Further work is necessary to determine the ubiquity and specificity of these associations and their functional consequences.

Plant community composition has also been implicated as a driver of microbiome structure in switchgrass cropping systems. Where switchgrass is grown in intra- and interspecific plant mixtures, plant diversity is positively associated with $\beta$ diversity of the soil bacterial community (Jesus et al. 2016; Revillini et al. 2019). Switchgrass appears to harbor a less diverse AMF community than other tallgrass prairie plants or grass mixtures but a more abundant and diverse AMF community than monocultures of maize, Miscanthus spp., and bioswale plants (Brejda et al. 1993; Brodsky et al. 2019; Emery et al. 2017, 2018; Eom et al. 2000; Liang et al. 2016; Oates et al. 2016; Revillini et al. 2019; Singer et al. 2019b). Interestingly, Jesus et al. (2016) found that plant community composition was a stronger driver of switchgrass microbiome structure at older sites, suggesting that plant-driven effects on the microbiome develop over time and may not be detected during early years of plant establishment.

Plant growth architecture, tissue chemistry, and phenology, among other traits, can influence microbiome community structure in other plant hosts (Jones et al. 2019; Li et al. 2018). Several studies have shown that switchgrass genotype can shape root and rootinfluenced soil microbial communities (Emery et al. 2018; Revillini et al. 2019; Rodrigues et al. 2017; Sawyer et al. 2019; Singer et al. 2019a). Alphaproteobacteria appear to be more enriched in roots and soil associated with upland genotypes, while Actinobacteria and Acidobacteria are enriched in roots and soil associated with lowland genotypes (Revillini et al. 2019; Singer et al. 2019a). In contrast, there is little to no evidence for variation in AMF colonization rates due to switchgrass genotype (Brejda et al. 1998; Emery et al. 2018). Although links between specific switchgrass traits and microbiome structure have not been investigated explicitly, there is evidence suggesting that rooting and exudation patterns may shape microbiota in switchgrass-influenced soil (Emery et al. 2017; Mao et al. 2014). Members of the bacterial orders Burkholderiales and Xanthomonadales (both members of the phylum Proteobacteria) and the fungal orders Agaricales and Auriculariales (of the class Agaricomycetes) rapidly assimilated switchgrass root exudates to a greater degree than other bacteria and fungi, suggesting that there is a particularly close association between switchgrass and these organisms (Mao et al. 2014). Genetically engineered switchgrass lines may provide an opportunity to explore specific relationships between plant traits and

TABLE 3

Major findings related to function of the switchgrass (Panicum virgatum L.) microbiome

\begin{tabular}{|c|c|}
\hline Function, major finding & Reference \\
\hline \multicolumn{2}{|l|}{ Plant growth promotion } \\
\hline $\begin{array}{l}\text { More diverse foliar and rhizosphere microbial communities are } \\
\text { associated with higher-yielding switchgrass stands }\end{array}$ & Xia et al. 2018 \\
\hline $\begin{array}{l}\text { Inoculation with growth-promoting rhizobacteria can increase } \\
\text { biomass of field-grown switchgrass plants under some } \\
\text { conditions }\end{array}$ & Ker et al. 2012, 2014; Lowman et al. 2015 \\
\hline \multicolumn{2}{|l|}{ Nutrient acquisition } \\
\hline $\begin{array}{l}\text { Arbuscular mycorrhizal fungi improve plant nitrogen and } \\
\text { phosphorus nutrition, especially under stress or resource-limited } \\
\text { conditions }\end{array}$ & $\begin{array}{l}\text { Brejda et al. 1998; Johnson 1998; Clark 2002; Clark et al. 2005; } \\
\text { Schroeder-Moreno et al. 2012; Ker et al. 2014; Sun et al. } 2018\end{array}$ \\
\hline $\begin{array}{l}\text { Associative } \mathrm{N} \text { fixation supports switchgrass } \mathrm{N} \text { demand, sustaining } \\
\text { yields in unfertilized plots despite repeated annual biomass } \\
\text { harvests }\end{array}$ & Roley et al. 2018, 2019 \\
\hline $\begin{array}{l}\text { Burkholderia transformed with } \mathrm{N} \text {-fixing genes yield } \mathrm{N} \text {-fixation and } \\
\text { greater plant biomass when added to roots }\end{array}$ & Lowman et al. 2016 \\
\hline \multicolumn{2}{|l|}{ Drought tolerance } \\
\hline $\begin{array}{l}\text { Root fungal endophyte Serendipita vermifera is associated with } \\
\text { sustained biomass production during drought }\end{array}$ & Ghimire et al. 2011 \\
\hline $\begin{array}{l}\text { Foliar fungal endophytes improve transpiration efficiency and } \\
\text { survival during drought }\end{array}$ & Giauque et al. 2019 \\
\hline
\end{tabular}


plant-associated microbial communities. However, the only published studies exploring the effect of genetic modifications on the switchgrass microbiome found no difference between the microbial community associated with transgenic switchgrass plants with decreased levels of caffeic acid 3-O-methyltransferase (a modification that may increase the efficiency of bioenergy conversion) and the microbiome associated with nontransgenic plants (Baxter et al. 2014; Chauhan et al. 2014). Nevertheless, as switchgrass breeding and modification continues, future research should investigate nontarget outcomes of plant genotypic development on switchgrass-microbiome associations and function.

Site characteristics. Site characteristics are very strong drivers of switchgrass microbial community composition (Table 1, "Compared sites"), often explaining more variation in microbial communities than plant species or genotype (Brodsky et al. 2019; Giauque and Hawkes 2013; Hargreaves et al. 2015; Jesus et al. 2016; Mao et al. 2011, 2013; Soman et al. 2018; Whitaker et al. 2018; Zhang et al. 2017). Over $50 \%$ of the variation in switchgrass microbial community structure has been attributed to site characteristics (Mao et al. 2013). Site-level variables (e.g., soil texture, moisture, organic matter, and nutrient content) have been implicated by multiple researchers as contributing to site-level variation in switchgrass microbial community composition (Giauque and Hawkes 2013; Jesus et al. 2016; Xia et al. 2018; Zhang et al. 2017). At two switchgrass sites in the midwestern United States, soil texture and fertility were the primary site-level variables driving differences between microbial communities (Jesus et al. 2016). Depth within the soil profile is also strongly associated with bacterial community structure in several bioenergy cropping systems, including switchgrass (Zhang et al. 2017). Genera characteristic of the deep soil profile under switchgrass $(25$ to $50 \mathrm{~cm}$ ) include Acinetobacter, Corynebacterium, Neisseria, and Prosthecobacter (Zhang et al. 2017), although it is difficult to identify causal relationships from these observations because several edaphic characteristics vary with depth. Latitude, $\mathrm{pH}$, phosphorus, and calcium were most strongly correlated with variation in bacterial community structure in switchgrass-influenced soil at eight sites across Illinois (Soman et al. 2018). Overall, although several studies attribute differences in microbial community structure to edaphic characteristics, few studies have investigated the mechanistic links between site characteristics and microbial taxa through manipulative experiments.

The studies that have conducted environmental manipulations to examine the switchgrass microbiome's response to environmental variables and management practices (Table 1, "Manipulated resources" and "Compared/manipulated host") have most frequently investigated $\mathrm{N}$ application. $\mathrm{N}$ inputs have varying effects on the switchgrass microbiome, ranging from no effect to significant changes in microbial community structure (Chen et al. 2019; Grady et al. 2019; Jach-Smith and Jackson 2018, 2020; Oates et al. 2016; Revillini et al. 2019). N fertilization at a rate of $56 \mathrm{~kg} \mathrm{ha}^{-1} \mathrm{year}^{-1}$, which is within the recommended range for switchgrass, reduced soil microbial biomass in switchgrass as well as Miscanthus stands and mixed prairie stands (Oates et al. 2016). AMF abundance was reduced in switchgrass stands with increasing $\mathrm{N}$ inputs, thereby diminishing mycorrhizal-derived nutrient acquisition (Jach-Smith and Jackson 2018, 2020; Oates et al. 2016). $\mathrm{N}$ fertilization at a rate of $67 \mathrm{~kg} \mathrm{ha}^{-1}$ year $^{-1}$ has also been associated with reduced nifH gene abundance in switchgrass roots (Revillini et al. 2019), and fertilization at a rate of $196 \mathrm{~kg} \mathrm{ha}^{-1}$ year $^{-1}$ was associated with a difference in $\beta$ diversity of nifH genes found in switchgrass root, leaf, and stem tissues, as well as switchgrass-associated soils (Roley et al. 2019). Taken together, these findings suggest that fertilization may influence the potential contribution of associative $\mathrm{N}$ fixation to switchgrass nutrition. Grady et al. (2019) found that $\mathrm{N}$ fertilization applied at $56 \mathrm{~kg} \mathrm{ha}^{-1} \mathrm{year}^{-1}$ did not affect switchgrass bacterial and archaeal composition in the phyllosphere. However, it is not clear whether this is due to the moderate fertilization rate used in this study or because the phyllosphere microbiome is less directly affected by fertilization compared with the soil and root microbiome (e.g., due to rapid fertilizer-induced changes in soil $\mathrm{pH}$ ). To date, relatively few studies have investigated the effect of other management practices on the switchgrass microbiome such as biocide applications (Hartnett et al. 1994; Interrante et al. 2015), tillage regimes, and harvest practices.

Climate and seasonal variation. Understanding the effect of climate and seasonal variation on the switchgrass microbiome may help optimize management and predict bioenergy productivity under different global change scenarios. Studies investigating switchgrass microbiome response to climate have yielded mixed results. Together, recent spring rainfall and mean annual precipitation explained approximately $35 \%$ of the variation in switchgrass fungal endophytes cultured from shoot tissues collected across a 50$\mathrm{cm}$ precipitation gradient spanning $400 \mathrm{~km}$ (Giauque and Hawkes 2013). The authors suggest that water limitation may contribute to habitat filtering of fungal endophytes through its influence on plant productivity and fungal dispersion. In a study of bacterial and archaeal $\mathrm{N}$-cycling organisms across a $5^{\circ} \mathrm{C}$ gradient in average annual temperature and $30-\mathrm{cm}$ gradient in average annual rainfall, climate was poorly associated with community composition in switchgrass-associated soils (Mao et al. 2013). However, the authors did observe variation in nifH richness across this climatic gradient. They attributed this to a combination of higher temperature and precipitation in southern sites, positing that this provided conditions favorable to nitrogenase activity. These studies illustrate that climate can shape switchgrass microbiome composition in complex ways, with implications for plant and ecosystem function. Additional research investigating microbiome response to climatic gradients would help us understand and predict the impact of changes on key taxa (e.g., $\mathrm{N}$ fixers, AMF, and other mutualists).

Studies investigating seasonal and annual variation in switchgrass microbiome community composition (Table 1, "Compared timepoints") suggest that variation may be related to a combination of climatic conditions and seasonal patterns in plant metabolic activity or biochemical status (Chen et al. 2019; Ghimire et al. 2011; Grady et al. 2019; Rodrigues et al. 2017; Sawyer et al. 2019). Seasonal trends in the switchgrass microbiome appear to be both cultivar and compartment specific (Ghimire et al. 2011; Rodrigues et al. 2017). In the switchgrass phyllosphere, cumulative bacterial richness increases until early summer and then begins to taper off until plant senescence (Grady et al. 2019). Trends in relative abundance within the phylum Proteobacteria also follow a seasonal pattern in the phyllosphere, with an increase in Alphaproteobacteria and decrease in Gammaproteobacteria over the course of the growing season. The greatest plant cultivar-driven microbiome differences have been observed approximately 1.5 months into vegetative growth and were also associated with differences in overall cultivar productivity, belowground carbon allocation, and profile of amino acids exuded (Rodrigues et al. 2017). This underscores the necessity to consider temporal dynamics and interactive effects when assessing the composition and activity of the switchgrass microbiome.

\section{FUNCTIONAL ROLE OF THE SWITCHGRASS MICROBIOME}

Switchgrass-associated microbial taxa represent a wide range of life strategies and metabolic capacities, with potential to benefit 
plant production through contributions to plant nutrition, drought tolerance, and other functions. Below, we summarize findings from observational and manipulative studies investigating the functional role of the switchgrass microbiome.

Plant growth promotion. One motivation for interest in the switchgrass microbiome is its potential to promote plant growth. Studies investigating microbial effects on switchgrass yields report variable outcomes, including both positive and negative responses to bacteria and fungi inhabiting shoots, roots, and root-influenced soil, depending on the microorganisms in question (Table 1, "Measured biomass") (Fig. 2G) (Brejda et al. 1998; Giauque et al. 2019; Kleczewski et al. 2012; Lowman et al. 2015, 2016; Wang et al. 2016; Xia et al. 2018). The most notable responses have been observed in studies of mycorrhizal fungi (Awoyemi et al. 2019; Brejda et al. 1993; Clark et al. 1999a,b, 2005; Ghimire et al. 2011, 2009; Perumal and Maun 1999; Ray et al. 2015), which have been associated with more than a 50-fold increase in plant biomass-from less than $25 \mathrm{mg}$ of combined root and shoot biomass in uninoculated plants to more than $1,250 \mathrm{mg}$ in plants grown with Glomus clarum for 88 days (Clark et al. 1999a). There is also evidence that microbiome diversity and multitrophic interactions may be positively associated with switchgrass productivity, as has been observed in other plant systems (Bukovská et al. 2018; Hestrin et al. 2019; Lau and Lennon 2011). For example, higher-yielding switchgrass stands were correlated with more diverse foliar and rhizosphere microbial communities (Xia et al. 2018). Additionally, inoculation with both rhizosphere bacteria and fungi increased plant biomass production by up to 15 -fold relative to inoculation with rhizosphere bacteria alone (Brejda et al. 1998).

Some evidence suggests that switchgrass growth-promoting microbial consortia can be quite specific. For example, seedlings inoculated with rhizosphere inocula prepared from switchgrass fields were 1.5-fold larger than seedlings inoculated with rhizosphere inocula prepared from native prairies (Brejda et al. 1998). However, further research is necessary to determine whether switchgrass actively recruits beneficial microbiota and how specific taxa contribute to plant growth outcomes. Primary mechanisms for microbiome-driven plant growth promotion observed in other plant systems include improved resource acquisition, resource use efficiency, and tolerance to biotic and abiotic stress (Porter et al. in press). Below, we summarize evidence for these mechanisms in switchgrass-microbiome interactions.

Improved drought tolerance and water use efficiency. Low soil moisture availability can limit switchgrass productivity, particularly in marginal soils (Wang et al. 2010). Multiple studies have shown that root and foliar fungal endophytes enhance switchgrass productivity under water-limited conditions (Ghimire and Craven 2011; Ghimire et al. 2011; Giauque et al. 2019; Wang et al. 2016). When colonized by the root endophyte Serendipita vermifera, the biomass of switchgrass plants exposed to drought was up to $300 \%$ greater than that of uninoculated plants (Ghimire and Craven 2011). Under drought conditions, foliar fungal endophytes have been linked to both positive and negative effects on switchgrass biomass production, transpiration efficiency, wilt, and survival (Connor et al. 2017; Giauque et al. 2019). Fungi that were associated with greater shoot biomass under drought conditions were tolerant of osmotic stress, grew well on carboxylic acid substrates, produced greater mycelial biomass in culture, or originated from sites with higher mean annual temperatures (Giauque et al. 2019).

There is some evidence that a legacy of drought may select for microbial traits that improve plant water use efficiency. In a greenhouse manipulation, fungal endophytes from drier western sites reduced plant water loss compared with those from wetter eastern sites (Giauque and Hawkes 2013). Interestingly, most fungal endophytes were associated with a substantial increase in plant trait plasticity, suggesting that relationships between switchgrass and its microbiome may play an important role in plant adaptation to global change (Giauque and Hawkes 2013). Taken together, these studies illustrate that the switchgrass microbiome can mediate plant performance under water-limited conditions. Future work should continue to investigate the taxonomic specificity and functional outcome of these relationships and extend these studies to include bacteria and interactive effects. For example, because plant genotype is associated with both drought tolerance and microbiome structure, an examination of the interaction between these two selective forces would be valuable (Emery et al. 2018; Hartman et al. 2012; Revillini et al. 2019; Robins 2012; Rodrigues et al. 2017; Sawyer et al. 2019; Singer et al. 2019a).

Improved nutrient acquisition. Nutrient deficiencies pose a significant constraint to switchgrass production across many locations and management systems (Kering et al. 2012a,b; Muir et al. 2001; Wang et al. 2010). The microbiome can play an important role in plant nutrition through its effect on plant nutrient uptake, nutrient cycling, and promotion of root growth (Jacoby et al. 2017; Vacheron et al. 2013). Enhanced switchgrass $\mathrm{N}$ and phosphorus acquisition has been attributed to diazotrophic bacteria and mycorrhizal fungi (Brejda et al. 1998; Clark et al. 1999b, 2005; Ghimire and Craven 2011; Schroeder-Moreno et al. 2012) (see subsections below for further discussion, Table 1 "Measured nutrient content", and Figure 2G for summaries of studies assessing microbiome contributions to switchgrass nutrition). Switchgrass grown with a rhizosphere microbial inoculum containing both bacteria and fungi took up 6-fold more $\mathrm{N}$ and 36-fold more phosphorus than plants grown with a microbial inoculum prepared from rhizosphere bacteria only (Brejda et al. 1998). These results suggest that soil fungi facilitate switchgrass nutrient acquisition. However, future studies could expand on this work to identify whether such a growth stimulus is driven primarily by fungal activity, the nutrient content of the inoculum itself, or synergistic interactions between fungi and other microbial groups. Research in other grass systems suggests that multitrophic interactions between mycorrhizal fungi and other organisms facilitate plant nutrient acquisition (Bukovská et al. 2018; Hestrin et al. 2019). The microbiome's capacity to enhance plant nutrition is also mediated by environmental conditions such as seasonal dynamics, soil nutrient concentrations, $\mathrm{pH}$, and moisture availability (Jach-Smith and Jackson 2020; Ker et al. 2012; Roley et al. 2019, 2018). Because the majority of studies investigating switchgrass functional response to microbial taxa focus on diazotrophic bacteria and mycorrhizal fungi, further details regarding these interactions are summarized below.

Role of associative N-fixing organisms. $\mathrm{N}$ fixation activity, driven by diazotrophs, has been documented in all switchgrass compartments (Roley et al. 2019). This diazotrophic community is both abundant and diverse, with over 400 putative $\mathrm{N}$-fixers identified from the phyla Proteobacteria, Firmicutes, Cyanobacteria, Verrucomicrobia, and others (Table 1, "N-fixing organisms") (Bahulikar et al. 2014, 2021; Roley et al. 2019; Singer et al. 2019a). Several studies have investigated how associative N-fixing organisms contribute to switchgrass $\mathrm{N}$ nutrition and productivity (Table 1, "N-fixing organisms") (Bauer et al. 2012; Fei et al. 2017; Ker et al. 2012, 2014; Lowman et al. 2015, 2016; Roley et al. 2018, 2019). Associative $\mathrm{N}$ fixation appears to account for a substantial portion of switchgrass $\mathrm{N}$ demand, sustaining yields in unfertilized plots despite repeated annual biomass harvests (Roley et al. 2018, 2019). Inoculation with N-fixing bacteria has also been associated with a $69 \%$ increase in switchgrass biomass under low $\mathrm{N}$ conditions in a controlled growth-chamber study (Lowman et al. 2016). In an 
earlier study, Lowman et al. (2015) also found that inoculation of field-grown switchgrass with Burkholderia phytofirmans strain PsJN significantly stimulated plant growth and tiller number in a low-fertility soil. However, Fei et al. (2017) found that field application of $\mathrm{N}$-fixing organisms did not improve wild-type switchgrass productivity, despite promising results in a greenhouse experiment. Bahulikar et al. (2014) demonstrated that only one-third of the putative diazotrophs identified in switchgrass roots using a taxonomic marker also contained active nifH genes at the time of sampling. Of these, organisms belonging to the class Alphaproteobacteria predominated and the species Rhizobium helanshanens alone accounted for over $30 \%$ of nifH RNA sequences. This indicates that, although switchgrass can host many putative diazotrophs, only a few taxa may be actively fixing $\mathrm{N}$ that can be supplied to the plant. It is possible that weak plant growth responses to $\mathrm{N}$-fixing organisms are mediated by environmental conditions that control $\mathrm{N}$ fixation. Ker et al. (2012) found that the addition of a bacterial consortium containing $\mathrm{N}$-fixing organisms enhanced switchgrass biomass grown on clay and clay loam soils but not on fine sandy loam. They concluded that moisture limitation in the sandy loam inhibited $\mathrm{N}$ fixation. Nitrogen fixation rates also vary seasonally and decline in response to long-term $\mathrm{N}$ fertilizer additions (Roley et al. 2018, 2019). Future research should continue to investigate the complex factors controlling interactions between $\mathrm{N}$-fixing microorganisms and switchgrass, and assess the mechanisms driving contributions of N-fixers to switchgrass biomass production.

Role of mycorrhizal fungi. Mycorrhizal inoculation has frequently been associated with benefits to switchgrass production (Table 1, "Mycorrhizal fungi"), including increased plant biomass (Awoyemi et al. 2019; Brejda et al. 1993; Clark et al. 1999a, 2005; Entry et al. 1999; Ghimire and Craven 2011; Ghimire et al. 2009; Perumal and Maun 1999; Ray et al. 2015; Sun et al. 2018), improved nutrient economies (Brejda et al. 1993; Clark 2002; Clark et al. 1999b, 2005; Ghimire and Craven 2011; Schroeder-Moreno et al. 2012; Sun et al. 2018), tolerance to abiotic stress (e.g., drought, soil acidity, and heavy metal toxicity) (Clark et al. 1999a, 2005; Ghimire and Craven 2011; Sun et al. 2018), and higher seed germination rates (Awoyemi et al. 2019; Ghimire et al. 2009). Switchgrass-associated mycorrhizal fungi also appear to provide their host plant protection against biotic stress agents such as parasitic nematodes (Emery et al. 2017; Schouteden et al. 2015). In addition, association with mycorrhizal fungi can alter plant resource allocation in favor of more efficient growth. For example, efficient allocation of plant photosynthates may explain observations of lower root biomass in mycorrhizal plants whose extensive hyphal networks may access a similar pool of resources at a lower carbon cost to the plant (Schroeder-Moreno et al. 2012; Veresoglou et al. 2012).

Although several studies have documented switchgrass-mycorrhizal associations (Table 1, "Mycorrhizal fungi"), some of these relationships may be context dependent and do not consistently lead to improved switchgrass performance (Clark et al. 1999b, 2005; Johnson 1998; Schroeder-Moreno et al. 2012). In acidic soils, colonization by some AMF species was linked to reduced shoot biomass and nutrient concentrations compared with uncolonized plants (Clark et al. 1999b, 2005). Johnson (1998) found that, although AMF were associated with substantially increased biomass under phosphorus-limited conditions, this was not true in highphosphorus soils. $\mathrm{N}$ fertilization has also been associated with diminished mycorrhizal contributions to switchgrass nutrition (Jach-Smith and Jackson 2018). Taken together, these observations suggest that, although switchgrass hosts may frequently be colonized by AMF (Emery et al. 2017; Jansa et al. 2003), they are not equally responsive across all environmental conditions (Emery et al. 2018). Future work should continue to assess the contribution of mycorrhizal fungi to switchgrass productivity and stress tolerance, particularly under marginal growing conditions and in conjunction with fertilizer and harvest manipulations.

Role of viruses and eukaryotes. A small number of studies have investigated interactions between switchgrass and viruses or microeukaryotes outside the context of pest or pathogenic interactions (Alexander et al. 2017; Emery et al. 2017; Mao et al. 2014). Microeukaryotes belonging to the groups Alveolata, Metazoa, Rhizaria, Stramenopiles, and Amoebozoa can be both abundant and active in switchgrass-associated soil-rapidly assimilating plantderived carbon into their biomass-but their function in switchgrass ecosystems remains largely unknown (Mao et al. 2014). Switchgrass may harbor a more diverse and abundant nematode community compared with other bioenergy crops (Emery et al. 2017). Dominant groups of nematodes identified in switchgrass stands include plant-parasitic nematodes in the family Tylenchidae and bacteria-feeding nematodes in the family Cephalobidae (Emery et al. 2017). Although parasitic nematodes can significantly reduce plant productivity, nematode communities have also been implicated in terrestrial nutrient cycling and enhanced plant nutrient acquisition (Gebremikael et al. 2016). Although switchgrass is considered to be relatively pathogen resistant, viral infection has been associated with reduced switchgrass growth and fitness (Alexander et al. 2017). Soil viral communities may also influence plant outcomes through their effects on soil organic matter turnover and microbial community dynamics (Williamson et al. 2017) but, to date, no published studies investigate the role of switchgrassassociated viruses that are not directly implicated in plant disease. These complex relationships play an important role in plant fitness and warrant further research.

\section{TAXONOMIC DISTRIBUTION OF SWITCHGRASS- CULTURED ISOLATES}

Taxa cultured from switchgrass tissues and soils represent experimentally tractable candidates for further research on switchgrass-microbe interactions and development of plant-growthpromoting inoculants. Because microbial culturing conditions (e.g., media type, plate size, and laboratory climate) often favor ruderal organisms that are tolerant to the relatively narrow range of conditions provided in the laboratory, only a small portion of the Earth's microbial species have been successfully cultured to date (Rappé and Giovannoni 2003; Stewart 2012). The proportion of switchgrass-associated microbes that have been cultured is unknown. However, the taxa that have been isolated through culturedependent approaches can be manipulated to provide mechanistic insight and, therefore, are of potential interest to the scientific community.

We summarized the taxonomic distribution of organisms cultured from switchgrass in eight studies that reported results with metadata suitable for synthesis (Supplementary Table S2) (Eom et al. 2000; Gagne-Bourgue et al. 2013; Giauque and Hawkes 2013; Kleczewski et al. 2012; Luo et al. 2017; Whitaker et al. 2018; Xia et al. 2013, 2018). These include four studies of organisms cultured from shoot tissues, one study of organisms cultured from root tissues, two studies of organisms cultured from both root and shoot tissues, and one live plant trap culture used to isolate mycorrhizal spores. A visual summary of the taxa cultured from switchgrass is provided in Figure 3. In several studies, the authors inoculated live switchgrass plants with the cultured organisms in subsequent experiments to investigate plant response (Giauque and Hawkes 2013; Kleczewski et al. 2012; Xia et al. 2013, 2018) (see results described above). 
Only two of eight studies cultured bacteria from switchgrass tissues. Phylum-level bacterial diversity was distributed fairly evenly across the phyla Firmicutes, Proteobacteria, and Actinobacteria, and also included a few representatives from the phyla Bacteroidetes and Deinococcus-Thermus (Fig. 3A). Together, these five phyla included bacteria from a total of 24 genera, including both Gram-positive (Firmicutes, Actinobacteria, and DeinococcusThermus) and Gram-negative (Proteobacteria and Bacteroidetes) organisms. The most commonly isolated bacteria belonged to the genera Bacillus, Microbacterium, and Pseudomonas. Although experimental conditions in culture-dependent studies often select for fast-growing bacteria such as Bacillus spp. and other members of the order Bacillales, related genera have also been found in association with switchgrass using culture-independent methods (Rodrigues et al. 2017). Bacillus spp. are considered a particularly attractive microbial inoculant due to their ability to form heat-resistant spores and survive seed-treatment processes (Yánez-Mendizábal et al. 2012). Pseudomonas spp. have also been identified in switchgrass using culture-independent methods (Grady et al. 2019) and investigated for their plant-growth-promoting activity (O'Callaghan 2016), while Microbacterium spp. may protect plants against pathogen damage and drought (Berendsen et al. 2018; Vílchez et al. 2018).

Compared with the studies of bacterial isolates, studies of fungal isolates reported a higher number of genera (79 fungal genera total reported in a total of six studies) but less even distribution across phyla. The majority of fungal taxa cultured belong to the phylum Ascomycota (Fig. 3B). The paucity of species belonging to the phylum Basidiomycota may be due to a culture-dependent bias against these organisms, which have been identified using cultureindependent approaches in other plant systems (Arnold et al. 2007). In collections of fungi cultured from both switchgrass root and shoot tissues, Sordariomycetes was the most abundant class of fungi, followed by Dothideomycetes, Eutiomycetes, and Letiomycetes. Although most studies of switchgrass-associated fungal isolates were conducted on petri plates, one study used live plant trap cultures to isolate arbuscular mycorrhizal spores (Eom et al. 2000), in which three fungal orders were identified: Glomerales, Diversiporales, and Gigasporales. Due to their obligate biotrophic lifestyles, Glomeromycota and other taxa dependent on associations with living plants are also likely underreported in most culturedependent studies. As with the order Bacillales and many of the bacterial species isolated from switchgrass, it is also likely that fast-growing fungal species with more ruderal lifestyles are favored in studies using a culture-dependent approach (Ohsowski et al. 2014).

Although culture-dependent approaches have significant limitations, they continue to provide an important resource for investigation of the plant microbiome. Recent advances in microbial culturing and inoculation technologies may help address these limitations (Bashan et al. 2014; Chaudhary et al. 2019). Sampling and culturing strategies that facilitate the growth of organisms with more diverse life strategy and phylogeny may be useful in subsequent research seeking to leverage culture collections to examine microbial effects on plant host phenotype and function.

\section{PERSPECTIVE}

Despite substantial interest in harnessing the microbiome for more sustainable bioenergy production, our understanding of key organisms, interactions, and mechanisms remains nascent. Even for $\mathrm{N}$-fixing diazotrophs and mycorrhizal fungi, whose contributions to plant nutrition have been relatively well documented, there remain many fundamental unknowns regarding their relationships with switchgrass. Our review of the literature highlights a particular need for research on understudied organisms such as viruses and nonfungal microeukaryotes (Gao et al. 2019; Williamson et al. 2017), as well as nonmycorrhizal fungi, whose activity can affect critical soil processes and plant physiology (Almario et al. 2017). Likewise, although evidence from other terrestrial ecosystems demonstrates that multitrophic interactions play an important role in nutrient turnover, plant productivity, and ecosystem function (Koller et al. 2013; Williamson et al. 2017), our understanding of multitrophic interactions in switchgrass systems remains limited. Other lines of research should include examination of the microbiome's role in plant establishment and resilience following disturbance or stress, spatiotemporal variation in microbiome structure and function, ecosystem services provided by the microbiome (e.g., soil carbon storage, soil aggregation, reduced greenhouse gas emissions, enhanced biodiversity, and so on), and genomic mechanisms mediating plant-microbe interactions (Pett-Ridge et al. 2021). Additionally, in order to manage the switchgrass microbiome for bioenergy production, it will be necessary to evaluate microbial inoculation methods and persistence in field settings, economic feasibility, and optimal agricultural management practices. Particular attention should be paid to inoculation methods that have the potential to be widely adopted by farmers such as seed biopriming and encapsulation (Qiu et al. 2019).

Although resources for switchgrass research have increased substantially, the plant's large genome, stature, and tendency to outcross represent significant challenges to developing a mechanistic understanding of switchgrass-microbiome interactions at the molecular level. Knowledge established through other study systems can facilitate progress in switchgrass microbiome research. For example, experimentally tractable model systems such as Arabidopsis, Brachypodium, and P. hallii (a diploid genetic model for switchgrass) provide a foundation for our fundamental understanding of plant-microbiome interactions (Draper et al. 2001; Kawasaki et al. 2016; Lundberg et al. 2012; Meyer et al. 2012). When extrapolating findings from these systems to switchgrass, it is important to consider key genetic and physiological differences, including perennial growth habit, $\mathrm{C} 4$ metabolism, genome size, and capacity for mycorrhizal associations. To elucidate the effects of agricultural management practices and environmental conditions on switchgrass microbiome structure and function, research should leverage existing field trials that occur across climatic and edaphic gradients or are under different management regimes. Microbially explicit models, which attempt to enhance mechanistic representations of microbial activity, may also provide a useful framework for understanding plant-microbiome interactions within the context of biogeochemical cycles and ecosystem function (Malik et al. 2020; Wieder et al. 2015). Cross-disciplinary research in metabolic analysis, multiomics, remote sensing, and data science will further enable progress in switchgrass microbiome research and application. Similarly, more thorough reporting and accessibility of microbial data (e.g., as publicly available tables of amplicon sequence variants, along with the number of reads per sequence, sequencing depth, and other metadata) would also greatly facilitate the synthesis of observations across a wider range of environmental and experimental conditions (Edgar 2018). Together, this work will help elucidate the mechanisms through which the microbiome can enhance the productivity and sustainability of switchgrass bioenergy systems.

\section{ACKNOWLEDGMENTS}

We thank J. Yusko and E. Nuccio at Lawrence Livermore National Laboratory for assistance with graphic design. 


\section{LITERATURE CITED}

Alexander, H. M., Bruns, E., Schebor, H., and Malmstrom, C. M. 2017. Cropassociated virus infection in a native perennial grass: Reduction in plant fitness and dynamic patterns of virus detection. J. Ecol. 105:1021-1031.

Almario, J., Jeena, G., Wunder, J., Langen, G., Zuccaro, A., Coupland, G., and Bucher, M. 2017. Root-associated fungal microbiota of nonmycorrhizal Arabis alpina and its contribution to plant phosphorus nutrition. Proc. Natl. Acad. Sci. U.S.A. 114:E9403-E9412.

Arnold, A. E., Henk, D. A., Eells, R. L., Lutzoni, F., and Vilgalys, R. 2007. Diversity and phylogenetic affinities of foliar fungal endophytes in loblolly pine inferred by culturing and environmental PCR. Mycologia 99:185-206.

Awoyemi, O. M., Adeleke, E. O., and Dzantor, E. K. 2019. Arbuscular mycorrhizal fungi and exogenous glutathione mitigate coal fly ash (CFA)induced phytotoxicity in CFA-contaminated soil. J. Environ. Manage. 237: 449-456.

Bahulikar, R. A., Chaluvadi, S. R., Torres-Jerez, I., Mosali, J., Bennetzen, J. L., and Udvardi, M. 2021. Nitrogen fertilization reduces nitrogen fixation activity of diverse diazotrophs in switchgrass roots. Phytobiomes J. 5:80-87.

Bahulikar, R. A., Torres-Jerez, I., Worley, E., Craven, K., and Udvardi, M. K. 2014. Diversity of nitrogen-fixing bacteria associated with switchgrass in the native tallgrass prairie of northern Oklahoma. Appl. Environ. Microbiol. 80: 5636-5643.

Bashan, Y., de-Bashan, L. E., Prabhu, S. R., and Hernandez, J.-P. 2014. Advances in plant growth-promoting bacterial inoculant technology: Formulations and practical perspectives (1998-2013). Plant Soil 378:1-33.

Bauer, J. T., Kleczewski, N. M., Bever, J. D., Clay, K., and Reynolds, H. L. 2012. Nitrogen-fixing bacteria, arbuscular mycorrhizal fungi, and the productivity and structure of prairie grassland communities. Oecologia 170: 1089-1098.

Baxter, H. L., Mazarei, M., Labbe, N., Kline, L. M., Cheng, Q., Windham, M. T., Mann, D. G. J., Fu, C., Ziebell, A., Sykes, R. W., Rodriguez, M., Jr., Davis, M. F., Mielenz, J. R., Dixon, R. A., Wang, Z.-Y., and Stewart, C. N., Jr. 2014. Two-year field analysis of reduced recalcitrance transgenic switchgrass. Plant Biotechnol. J. 12:914-924.

Berendsen, R. L., Vismans, G., Yu, K., Song, Y., de Jonge, R., Burgman, W. P., Burmolle, M., Herschend, J., Bakker, P. A. H. M., and Pieterse, C. M. J. 2018. Disease-induced assemblage of a plant-beneficial bacterial consortium. ISME J. 12:1496-1507.

Bertagnolli, A. D., Meinhardt, K. A., Pannu, M., Brown, S., Strand, S., Fransen, S. C., and Stahl, D. A. 2015. Influence of edaphic and management factors on the diversity and abundance of ammonia-oxidizing thaumarchaeota and bacteria in soils of bioenergy crop cultivars. Environ. Microbiol. Rep. 7:312-320.

Bodenhausen, N., Horton, M. W., and Bergelson, J. 2013. Bacterial communities associated with the leaves and the roots of Arabidopsis thaliana. PLoS One 8: e56329.

Brejda, J. J., Moser, L. E., and Vogel, K. P. 1998. Evaluation of switchgrass rhizosphere microflora for enhancing seedling yield and nutrient uptake. Agron. J. 90:753-758.

Brejda, J. J., Yocom, D. H., Moser, L. E., and Waller, S. S. 1993. Dependence of 3 Nebraska sandhills warm-season grasses on vesicular-arbuscular mycorrhizae. J. Range Manage. 46:14-20.

Brodsky, O. L., Shek, K. L., Dinwiddie, D., Bruner, S. G., Gill, A. S., Hoch, J. M., Palmer, M. I., and McGuire, K. L. 2019. Microbial communities in bioswale soils and their relationships to soil properties, plant species, and plant physiology. Front. Microbiol. 10:2368.

Bukovská, P., Michael Bonkowski, M., Konvalinková, T., Beskid, O., Hujslová, M., Püschel, D., Řezáčová, V., Gutiérrez-Núñez, M. S., Gryndler, M., and Jansa, J. 2018. Utilization of organic nitrogen by arbuscular mycorrhizal fungi-is there a specific role for protists and ammonia oxidizers? Mycorrhiza 28:269-283.

Bulgarelli, D., Rott, M., Schlaeppi, K., Ver Loren van Themaat, E., Ahmadinejad, N., Assenza, F., Rauf, P., Huettel, B., Reinhardt, R., Schmelzer, E., Peplies, J., Gloeckner, F. O., Amann, R., Eickhorst, T., and Schulze-Lefert, P. 2012. Revealing structure and assembly cues for Arabidopsis root-inhabiting bacterial microbiota. Nature 488:91-95.

Casler, M. D. 2012. Switchgrass breeding, genetics, and genomics. Pages 29-53 in: Switchgrass, Green Energy and Technology. A. Monti, ed. SpringerVerlag, London, U.K.

Chaudhary, D. K., Khulan, A., and Kim, J. 2019. Development of a novel cultivation technique for uncultured soil bacteria. Sci. Rep. 9:6666.
Chauhan, A., Smartt, A., Wang, J., Utturkar, S., Frank, A., Bi, M., Liu, J., Williams, D., Xu, T., Eldridge, M., Arreaza, A., Rogers, A., Gonzalez, H. C., Layton, A. C., Baxter, H. L., Mazarei, M., DeBruyn, J. M., Stewart, C. N., Jr., Brown, S. D., Hauser, L. J., and Sayler, G. S. 2014. Integrated metagenomics and metatranscriptomics analyses of root-associated soil from transgenic switchgrass. Genome Announce. 4:e00777-14.

Chen, H., Yang, Z. K., Yip, D., Morris, R. H., Lebreux, S. J., Cregger, M. A., Klingeman, D. M., Hui, D., Hettich, R. L., Wilhelm, S. W., Wang, G., Löffler, F. E., and Schadt, C. W. 2019. One-time nitrogen fertilization shifts switchgrass soil microbiomes within a context of larger spatial and temporal variation. PLoS One 14:e0211310.

Clark, R. B. 2002. Differences among mycorrhizal fungi for mineral uptake per root length of switchgrass grown in acidic soil. J. Plant Nutr. 25: 1753-1772.

Clark, R. B., Baligar, V. C., and Zobel, R. W. 2005. Response of mycorrhizal switchgrass to phosphorus fractions in acidic soil. Commun. Soil Sci. Plant Anal. 36:1337-1359.

Clark, R. B., Zeto, S. K., and Zobel, R. W. 1999a. Arbuscular mycorrhizal fungal isolate effectiveness on growth and root colonization of Panicum virgatum in acidic soil. Soil Biol. Biochem. 31:1757-1763.

Clark, R. B., Zobel, R. W., and Zeto, S. K. 1999b. Effects of mycorrhizal fungus isolates on mineral acquisition by Panicum virgatum in acidic soil. Mycorrhiza 9:167-176.

Connor, E. W., Sandy, M., and Hawkes, C. V. 2017. Microbial tools in agriculture require an ecological context: Stress-dependent non-additive symbiont interactions. Agron. J. 109:917-926.

DeBruyn, J. M., Bevard, D. A., Essington, M. E., McKnight, J. Y., Schaeffer, S. M., Baxter, H. L., Mazarei, M., Mann, D. G. J., Dixon, R. A., Chen, F., Zhuo, C., Wang, Z.-Y., and Stewart, C. N. 2017. Field-grown transgenic switchgrass (Panicum virgatum L.) with altered lignin does not affect soil chemistry, microbiology, and carbon storage potential. GCB Bioenergy 9:1100-1109.

Draper, J., Mur, L. A., Jenkins, G., Ghosh-Biswas, G. C., Bablak, P., Hasterok, R., and Routledge, A. P. 2001. Brachypodium distachyon. A new model system for functional genomics in grasses. Plant Physiol. 127:1539-1555.

Edgar, R. C. 2018. Updating the $97 \%$ identity threshold for 16 S ribosomal RNA OTUs. Bioinformatics 34:2371-2375.

Emery, S. M., Kinnetz, E. R., Bell-Dereske, L., Stahlheber, K. A., Gross, K. L., and Pennington, D. 2018. Low variation in arbuscular mycorrhizal fungal associations and effects on biomass among switchgrass cultivars. Biomass Bioenergy 119:503-508.

Emery, S. M., Reid, M. L., Bell-Dereske, L., and Gross, K. L. 2017. Soil mycorrhizal and nematode diversity vary in response to bioenergy crop identity and fertilization. GCB Bioenergy 9:1644-1656.

Entry, J. A., Watrud, L. S., and Reeves, M. 1999. Accumulation of 137Cs and $90 \mathrm{Sr}$ from contaminated soil by three grass species inoculated with mycorrhizal fungi. Environ. Pollut. 104:449-457.

Eom, A.-H., Hartnett, D. C., and Wilson, G. W. T. 2000. Host plant species effects on arbuscular mycorrhizal fungal communities in tallgrass prairie. Oecologia 122:435-444.

Fei, H., Crouse, M., Papadopoulos, Y., and Kevin Vessey, J. 2017. Enhancing the productivity of hybrid poplar (Populus $\times$ hybrid) and switchgrass (Panicum virgatum $\mathrm{L}$.) by the application of beneficial soil microbes and a seaweed extract. Biomass Bioenergy 107:122-134.

Fischer, M. A., Güllert, S., Neulinger, S. C., Streit, W. R., and Schmitz, R. A. 2016. Evaluation of 16S rRNA gene primer pairs for monitoring microbial community structures showed high reproducibility within and low comparability between datasets generated with multiple archaeal and bacterial primer pairs. Front. Microbiol. 7:1297.

Gagne-Bourgue, F., Aliferis, K. A., Seguin, P., Rani, M., Samson, R., and Jabaji, S. 2013. Isolation and characterization of indigenous endophytic bacteria associated with leaves of switchgrass (Panicum virgatum L.) cultivars. J. Appl. Microbiol. 114:836-853.

Gao, Z., Karlsson, I., Geisen, S., Kowalchuk, G., and Jousset, A. 2019. Protists: Puppet masters of the rhizosphere microbiome. Trends Plant Sci. 24:165-176.

Gebremikael, M. T., Steel, H., Buchan, D., Bert, W., and De Neve, S. 2016. Nematodes enhance plant growth and nutrient uptake under $\mathrm{C}$ and N-rich conditions. Sci. Rep. 6:32862.

Gelfand, I., Sahajpal, R., Zhang, X., Izaurralde, R. C., Gross, K. L., and Robertson, G. P. 2013. Sustainable bioenergy production from marginal lands in the US Midwest. Nature 493:514-517.

Ghimire, S. R., Charlton, N. D., Bell, J. D., Krishnamurthy, Y. L., and Craven, K. D. 2011. Biodiversity of fungal endophyte communities inhabiting switchgrass (Panicum virgatum L.) growing in the native tallgrass prairie of northern Oklahoma. Fungal Divers. 47:19-27. 
Ghimire, S. R., Charlton, N. D., and Craven, K. D. 2009. The mycorrhizal fungus, Sebacina vermifera, enhances seed germination and biomass production in switchgrass (Panicum virgatum L). Bioenergy Res. 2:51-58.

Ghimire, S. R., and Craven, K. D. 2011. Enhancement of switchgrass (Panicum virgatum L.) biomass production under drought conditions by the ectomycorrhizal fungus Sebacina vermifera. Appl. Environ. Microbiol. 77: 7063-7067.

Giauque, H., Connor, E. W., and Hawkes, C. V. 2019. Endophyte traits relevant to stress tolerance, resource use and habitat of origin predict effects on host plants. New Phytol. 221:2239-2249.

Giauque, H., and Hawkes, C. V. 2013. Climate affects symbiotic fungal endophyte diversity and performance. Am. J. Bot. 100:1435-1444.

Grady, K. L., Sorensen, J. W., Stopnisek, N., Guittar, J., and Shade, A. 2019. Assembly and seasonality of core phyllosphere microbiota on perennial biofuel crops. Nat. Commun. 10:4135.

Hargreaves, S. K., Williams, R. J., and Hofmockel, K. S. 2015. Environmental filtering of microbial communities in agricultural soil shifts with crop growth. PLoS One 10:e0134345.

Hartman, J. C., Nippert, J. B., and Springer, C. J. 2012. Ecotypic responses of switchgrass to altered precipitation. Funct. Plant Biol. 39:126-136.

Hartnett, D. C., Samenus, R. J., Fischer, L. E., and Hetrick, B. A. D. 1994. Plant demographic responses to mycorrhizal symbiosis in tallgrass prairie. Oecologia 99:21-26.

He, S., Guo, L., Niu, M., Miao, F., Jiao, S., Hu, T., and Long, M. 2017. Ecological diversity and co-occurrence patterns of bacterial community through soil profile in response to long-term switchgrass cultivation. Sci. Rep. 7:3608.

Hestrin, R., Hammer, E., Mueller, C., and Lehmann, J. 2019. Synergies between mycorrhizal fungi and soil microbial communities increase plant nitrogen acquisition. Commun. Biol. 2:233.

Interrante, S. M., Hancock, D., and Butler, T. J. 2015. Switchgrass establishment and biomass yield responses to fungicide and insecticide seed treatments. Crop Forage Turf. Manage. 1:1-6.

Jach-Smith, L. C., and Jackson, R. D. 2018. N addition undermines N supplied by arbuscular mycorrhizal fungi to native perennial grasses. Soil Biol. Biochem. 116:148-157.

Jach-Smith, L. C., and Jackson, R. D. 2020. Inorganic N addition replaces N supplied to switchgrass (Panicum virgatum) by arbuscular mycorrhizal fungi. Ecol. Appl. 30:e02047.

Jacoby, R., Peukert, M., Succurro, A., Koprivova, A., and Kopriva, S. 2017. The role of soil microorganisms in plant mineral nutrition-current knowledge and future directions. Front. Plant Sci. 8:1617.

Jansa, J., Mozafar, A., Kuhn, G., Anken, T., Ruh, R., Sanders, I. R., and Frossard, E. 2003. Soil tillage affects the community structure of mycorrhizal fungi in maize roots. Ecol. Appl. 13:1164-1176.

Jesus, E. C., Liang, C., Quensen, J. F., Susilawati, E., Jackson, R. D., Balser, T. C., and Tiedje, J. M. 2016. Influence of corn, switchgrass, and prairie cropping systems on soil microbial communities in the upper Midwest of the United States. GCB Bioenergy 8:481-494.

Johnson, N. C. 1998. Responses of Salsola kali and Panicum virgatum to mycorrhizal fungi, phosphorus and soil organic matter: Implications for reclamation. J. Appl. Ecol. 35:86-94.

Johnson, N. C., Rowland, D. L., Corkidi, L., and Allen, E. B. 2008. Plant winners and losers during grassland $\mathrm{N}$-eutrophication differ in biomass allocation and mycorrhizas. Ecology 89:2868-2878.

Jones, P., Garcia, B. J., Furches, A., Tuskan, G. A., and Jacobson, D. 2019. Plant host-associated mechanisms for microbial selection. Front. Plant Sci. 10:862.

Kawasaki, A., Donn, S., Ryan, P. R., Mathesius, U., Devilla, R., Jones, A., and Watt, M. 2016. Microbiome and exudates of the root and rhizosphere of Brachypodium distachyon, a model for wheat. PLoS One 11:e0164533.

Ker, K., Seguin, P., Driscoll, B. T., Fyles, J. W., and Smith, D. L. 2012. Switchgrass establishment and seeding year production can be improved by inoculation with rhizosphere endophytes. Biomass Bioenergy 47:295-301.

Ker, K., Seguin, P., Driscoll, B. T., Fyles, J. W., and Smith, D. L. 2014. Evidence for enhanced $\mathrm{N}$ availability during switchgrass establishment and seeding year production following inoculation with rhizosphere endophytes. Arch. Agron. Soil Sci. 60:1553-1563.

Kering, M. K., Biermacher, J. T., Butler, T. J., Mosali, J., and Guretzky, J. A. 2012a. Biomass yield and nutrient responses of switchgrass to phosphorus application. Bioenergy Res. 5:71-78.

Kering, M. K., Butler, T. J., Biermacher, J. T., and Guretzky, J. A. 2012 b. Biomass yield and nutrient removal rates of perennial grasses under nitrogen fertilization. Bioenergy Res. 5:61-70.
Kim, S., Lowman, S., Hou, G., Nowak, J., Flinn, B., and Mei, C. 2012. Growth promotion and colonization of switchgrass (Panicum virgatum) cv. Alamo by bacterial endophyte Burkholderia phytofirmans strain PsJN. Biotechnol. Biofuels 5:37.

Kleczewski, N. M., Bauer, J. T., Bever, J. D., Clay, K., and Reynolds, H. L. 2012. A survey of endophytic fungi of switchgrass (Panicum virgatum) in the Midwest, and their putative roles in plant growth. Fungal Ecol. 5: 521-529.

Koller, R., Rodriguez, A., Robin, C., Scheu, S., and Bonkowski, M. 2013. Protozoa enhance foraging efficiency of arbuscular mycorrhizal fungi for mineral nitrogen from organic matter in soil to the benefit of host plants. New Phytol. 199:203-211.

Kraut-Cohen, J., Zolti, A., Shaltiel-Harpaz, L., Argaman, E., Rabinovich, R., Green, S. J., and Minz, D. 2020. Effects of tillage practices on soil microbiome and agricultural parameters. Sci. Total Environ. 705:135791.

Lau, J. A., and Lennon, J. T. 2011. Evolutionary ecology of plant-microbe interactions: Soil microbial structure alters selection on plant traits. New Phytol. 192:215-224.

Li, Y., Wu, X., Chen, T., Wang, W., Liu, G., Zhang, W., Li, S., Wang, M., Zhao, C., Zhou, H., and Zhang, G. 2018. Plant phenotypic traits eventually shape its microbiota: A common garden test. Front. Microbiol. 9:2479.

Liang, C., Jesus, E. da C., Duncan, D. S., Quensen, J. F., Jackson, R. D., Balser, T. C., and Tiedje, J. M. 2016. Switchgrass rhizospheres stimulate microbial biomass but deplete microbial necromass in agricultural soils of the upper Midwest, USA. Soil Biol. Biochem. 94:173-180.

Liang, Y., Meggo, R., Hu, D., Schnoor, J. L., and Mattes, T. E. 2015. Microbial community analysis of switchgrass planted and unplanted soil microcosms displaying PCB dechlorination. Appl. Microbiol. Biotechnol. 99:6515-6526.

Liebig, M. A., Schmer, M. R., Vogel, K. P., and Mitchell, R. B. 2008. Soil carbon storage by switchgrass grown for bioenergy. Bioenergy Res. 1: 215-222.

Lowman, S., Kim-Dura, S., Mei, C., and Nowak, J. 2016. Strategies for enhancement of switchgrass (Panicum virgatum L.) performance under limited nitrogen supply based on utilization of $\mathrm{N}$-fixing bacterial endophytes. Plant Soil 405:47-63.

Lowman, S., Lava-Chavez, A., Kim-Dura, S., Flinn, B., Nowak, J., and Mei, C. 2015. Switchgrass field performance on two soils as affected by bacterization of seedlings with Burkholderia phytofirmans strain PsJN. Bioenerg. Res. 8: 440-449.

Lowry, D. B., Behrman, K. D., Grabowski, P., Morris, G. P., Kiniry, J. R., and Juenger, T. E. 2014. Adaptations between ecotypes and along environmental gradients in Panicum virgatum. Am. Nat. 183:682-692.

Lundberg, D. S., Lebeis, S. L., Paredes, S. H., Yourstone, S., Gehring, J., Malfatti, S., Tremblay, J., Engelbrektson, A., Kunin, V., Del Rio, T. G., Edgar, R. C., Eickhorst, T., Ley, R. E., Hugenholtz, P., Tringe, S. G., and Dangl, J. L. 2012. Defining the core Arabidopsis thaliana root microbiome. Nature 488:86-90.

Luo, J., Walsh, E., Miller, S., Blystone, D., Dighton, J., and Zhang, N. 2017. Root endophytic fungal communities associated with pitch pine, switchgrass, and rosette grass in the pine barrens ecosystem. Fungal Biol. 121: 478-487.

Malik, A. A., Martiny, J. B. H., Brodie, E. L., Martiny, A. C., Treseder, K. K., and Allison, S. D. 2020. Defining trait-based microbial strategies with consequences for soil carbon cycling under climate change. ISME J. 14:1-9.

Mao, Y., Li, X., Smyth, E. M., Yannarell, A. C., and Mackie, R. I. 2014. Enrichment of specific bacterial and eukaryotic microbes in the rhizosphere of switchgrass (Panicum virgatum L.) through root exudates. Environ. Microbiol. Rep. 6:293-306.

Mao, Y., Yannarell, A. C., Davis, S. C., and Mackie, R. I. 2013. Impact of different bioenergy crops on N-cycling bacterial and archaeal communities in soil. Environ. Microbiol. 15:928-942.

Mao, Y., Yannarell, A. C., and Mackie, R. I. 2011. Changes in N-transforming archaea and bacteria in soil during the establishment of bioenergy crops. PLoS One 6:e24750

McLaughlin, S. B., and Kszos, L. A. 2005. Development of switchgrass (Panicum virgatum) as a bioenergy feedstock in the United States. Biomass Bioenergy 28:515-535.

Meinhardt, K. A., Stopnisek, N., Pannu, M. W., Strand, S. E., Fransen, S. C., Casciotti, K. L., and Stahl, D. A. 2018. Ammonia-oxidizing bacteria are the primary $\mathrm{N} 2 \mathrm{O}$ producers in an ammonia-oxidizing archaea dominated alkaline agricultural soil. Environ. Microbiol. 20:2195-2206.

Meyer, E., Logan, T. L., and Juenger, T. E. 2012. Transcriptome analysis and gene expression atlas for Panicum hallii var. filipes, a diploid model for biofuel research. Plant J. 70:879-890. 
Moher, D., Liberati, A., Tetzlaff, J., Altman, D. G., and The PRISMA Group. 2009. Preferred reporting items for systematic reviews and meta-analyses: The PRISMA statement. PLoS Med. 6:e1000097.

Muir, J. P., Sanderson, M. A., Ocumpaugh, W. R., Jones, R. M., and Reed, R. L. 2001. Biomass production of "Alamo" switchgrass in response to nitrogen, phosphorus, and row spacing. Agron. J. 93:896-901.

Nilsson, R. H., Larsson, K.-H., Taylor, A. F. S., Bengtsson-Palme, J., Jeppesen, T. S., Schigel, D., Kennedy, P., Picard, K., Glöckner, F. O., Tedersoo, L., Saar, I., Kõljalg, U., and Abarenkov, K. 2019. The UNITE database for molecular identification of fungi: Handling dark taxa and parallel taxonomic classifications. Nucleic Acids Res. 47:D259-D264.

Oates, L. G., Duncan, D. S., Sanford, G. R., Liang, C., and Jackson, R. D. 2016. Bioenergy cropping systems that incorporate native grasses stimulate growth of plant-associated soil microbes in the absence of nitrogen fertilization. Agric. Ecosyst. Environ. 233:396-403.

O’Brien, S. L., Gibbons, S. M., Owens, S. M., Hampton-Marcell, J., Johnston, E. R., Jastrow, J. D., Gilbert, J. A., Meyer, F., and Antonopoulos, D. A. 2016. Spatial scale drives patterns in soil bacterial diversity. Environ. Microbiol. 18: 2039-2051.

O'Callaghan, M. 2016. Microbial inoculation of seed for improved crop performance: Issues and opportunities. Appl. Microbiol. Biotechnol. 100: 5729-5746.

Ohsowski, B. M., Zaitsoff, P. D., Öpik, M., and Hart, M. M. 2014. Where the wild things are: Looking for uncultured Glomeromycota. New Phytol. 204: 171-179.

Ondov, B. D., Bergman, N. H., and Phillippy, A. M. 2011. Interactive metagenomic visualization in a Web browser. BMC Bioinf. 12:385.

Orr, M.-J., Gray, M. B., Applegate, B., Volenec, J. J., Brouder, S. M., and Turco, R. F. 2015. Transition to second generation cellulosic biofuel production systems reveals limited negative impacts on the soil microbial community structure. Appl. Soil Ecol. 95:62-72.

Perumal, J. V., and Maun, M. A. 1999. The role of mycorrhizal fungi in growth enhancement of dune plants following burial in sand. Funct. Ecol. 13: 560-566.

Petipas, R. H., Bowsher, A. W., Bekkering, C. S., Jack, C. N., McLachlan, E. E., White, R. A., Younginger, B. S., Tiemann, L. K., Evans, S. E., and Friesen, M. L. 2020. Interactive effects of microbes and nitrogen on Panicum virgatum root functional traits and patterns of phenotypic selection. Int. J. Plant Sci. $181: 20-32$

Pett-Ridge, J., Shi, J., Estera-Molina, K., Nuccio, E. E., Yuan, M., Rijkers, R., Swenson, T., Zhalnina, K., Northen, T., Zhou, J., and Firestone, M. K. 2021. Rhizosphere carbon turnover from cradle to grave: The role of microbe-plant interactions. Pages 51-73 in: Rhizosphere Biology: Interactions Between Microbes and Plants. Rhizosphere Biology. V. Gupta and A. Sharma, eds. Springer, Singapore

Porter, S. S., Bantay, R., Friel, C. A., Garoutte, A., Gdanetz, K., Ibarreta, K., Moore, B. M., Shetty, P., Siler, E., and Friesen, M. L. Beneficial microbes ameliorate abiotic and biotic sources of stress on plants. Funct. Ecol. In press. doi:10.1111/1365-2435.13499

Qiu, Z., Egidi, E., Liu, H., Kaur, S., and Singh, B. K. 2019. New frontiers in agriculture productivity: Optimised microbial inoculants and in situ microbiome engineering. Biotechnol. Adv. 37:107371.

Rappé, M. S., and Giovannoni, S. J. 2003. The uncultured microbial majority. Annu. Rev. Microbiol. 57:369-394.

Ray, P., Ishiga, T., Decker, S. R., Turner, G. B., and Craven, K. D. 2015. A novel delivery system for the root symbiotic fungus, Sebacina vermifera, and consequent biomass enhancement of low lignin COMT switchgrass lines. Bioenergy Res. 8:922-933.

Revillini, D., Wilson, G. W. T., Miller, R. M., Lancione, R., and Johnson, N. C. 2019. Plant diversity and fertilizer management shape the belowground microbiome of native grass bioenergy feedstocks. Front. Plant Sci. 10:1018.

Řezáčová, V., Gryndler, M., Bukovská, P., Šmilauer, P., and Jansa, J. 2016. Molecular community analysis of arbuscular mycorrhizal fungi-Contributions of PCR primer and host plant selectivity to the detected community profiles. Pedobiologia (Jena) 59:179-187

Robert, V., Vu, D., Amor, A. B. H., van de Wiele, N., Brouwer, C., Jabas, B., Szoke, S., Dridi, A., Triki, M., Daoud, S. B., Chouchen, O., Vaas, L., de Cock, A., Stalpers, J. A., Stalpers, D., Verkley, G. J. M., Groenewald, M., dos Santos, F. B., Stegehuis, G., Li, W., Wu, L., Zhang, R., Ma, J., Zhou, M., Gorjón, S. P., Eurwilaichitr, L., Ingsriswang, S., Hansen, K., Schoch, C., Robbertse, B., Irinyi, L., Meyer, W., Cardinali, G., Hawksworth, D. L., Taylor, J. W., and Crous, P. W. 2013. MycoBank gearing up for new horizons. IMA Fungus 4:371-379.
Robins, J. G. 2012. Variation within accessions of switchgrass germplasm for dry matter yield and forage quality in a semiarid environment. Crop Sci. 52: 2253-2261.

Rodrigues, R. R., Moon, J., Zhao, B., and Williams, M. A. 2017. Microbial communities and diazotrophic activity differ in the root-zone of Alamo and Dacotah switchgrass feedstocks. GCB Bioenergy 9:1057-1070.

Roesch, L. F. W., Camargo, F. A. O., Bento, F. M., and Triplett, E. W. 2008. Biodiversity of diazotrophic bacteria within the soil, root and stem of fieldgrown maize. Plant Soil 302:91-104.

Roley, S. S., Duncan, D. S., Liang, D., Garoutte, A., Jackson, R. D., Tiedje, J. M., and Robertson, G. P. 2018. Associative nitrogen fixation (ANF) in switchgrass (Panicum virgatum) across a nitrogen input gradient. PLoS One 13:e0197320.

Roley, S. S., Xue, C., Hamilton, S. K., Tiedje, J. M., and Philip Robertson, G. 2019. Isotopic evidence for episodic nitrogen fixation in switchgrass (Panicum virgatum L.). Soil Biol. Biochem. 129:90-98.

Sawyer, A., Staley, C., Lamb, J., Sheaffer, C., Kaiser, T., Gutknecht, J., Sadowsky, M. J., and Rosen, C. 2019. Cultivar and phosphorus effects on switchgrass yield and rhizosphere microbial diversity. Appl. Microbiol. Biotechnol. 103:1973-1987.

Schouteden, N., De Waele, D., Panis, B., and Vos, C. M. 2015. Arbuscular mycorrhizal fungi for the biocontrol of plant-parasitic nematodes: A review of the mechanisms involved. Front. Microbiol. 6:1280.

Schroeder-Moreno, M. S., Greaver, T. L., Wang, S., Hu, S., and Rufty, T. W. 2012. Mycorrhizal-mediated nitrogen acquisition in switchgrass under elevated temperatures and N enrichment. GCB Bioenergy 4:266-276.

Sher, Y., Baker, N. R., Herman, D. J., Fossum, C., Hale, L., Zhang, X.-X., Nuccio, E. E., Saha, M. C., Zhou, J., Pett-Ridge, J., and Firestone, M. K. 2020. Microbial extracellular polysaccharide production and aggregate stability controlled by Switchgrass (Panicum virgatum) root biomass and soil water potential. Soil Biol. Biochem. 143:107742.

Singer, E., Bonnette, J., Kenaley, S. C., Woyke, T., and Juenger, T. E. 2019a. Plant compartment and genetic variation drive microbiome composition in switchgrass roots. Environ. Microbiol. Rep. 11:185-195.

Singer, E., Bonnette, J., Woyke, T., and Juenger, T. E. 2019b. Conservation of endophyte bacterial community structure across two grass species. Front. Microbiol. 10:2181.

Slessarev, E. W., Nuccio, E. E., McFarlane, K. J., Ramon, C., Saha, M., Firestone, M. K., and Pett-Ridge, J. 2020. Quantifying the effects of switchgrass (Panicum virgatum) on deep organic $\mathrm{C}$ stocks using natural abundance ${ }^{14} \mathrm{C}$ in three marginal soils. GCB Bioenergy 12:834-847.

Soman, C., Keymer, D. P., and Kent, A. D. 2018. Edaphic correlates of feedstock-associated diazotroph communities. GCB Bioenergy 10:343-352.

Stewart, E. J. 2012. Growing unculturable bacteria. J. Bacteriol. 194:4151-4160.

Sun, H., Xie, Y., Zheng, Y., Lin, Y., and Yang, F. 2018. The enhancement by arbuscular mycorrhizal fungi of the Cd remediation ability and bioenergy quality-related factors of five switchgrass cultivars in Cd-contaminated soil. PeerJ 6:e4425

Vacher, C., Hampe, A., Porté, A. J., Sauer, U., Compant, S., and Morris, C. E. 2016. The phyllosphere: Microbial jungle at the plant-climate interface. Annu. Rev. Ecol. Evol. Syst. 47:1-24.

Vacheron, J., Desbrosses, G., Bouffaud, M.-L., Touraine, B., Moënne-Loccoz, Y., Muller, D., Legendre, L., Wisniewski-Dyé, F., and Prigent-Combaret, C. 2013. Plant growth-promoting rhizobacteria and root system functioning. Front. Plant Sci. 4:356.

Veresoglou, S. D., Menexes, G., and Rillig, M. C. 2012. Do arbuscular mycorrhizal fungi affect the allometric partition of host plant biomass to shoots and roots? A meta-analysis of studies from 1990 to 2010. Mycorrhiza 22:227-235

Vílchez, J. I., Niehaus, K., Dowling, D. N., González-López, J., and Manzanera, M. 2018. Protection of pepper plants from drought by Microbacterium sp. 3J1 by modulation of the plant's glutamine and $\alpha$-ketoglutarate content: A comparative metabolomics approach. Front. Microbiol. 9:284.

Wang, B., Seiler, J. R., and Mei, C. 2016. A microbial endophyte enhanced growth of switchgrass under two drought cycles improving leaf level physiology and leaf development. Environ. Exp. Bot. 122:100-108.

Wang, D., Lebauer, D. S., and Dietze, M. C. 2010. A quantitative review comparing the yield of switchgrass in monocultures and mixtures in relation to climate and management factors. GCB Bioenergy 2:16-25.

Werling, B. P., Dickson, T. L., Isaacs, R., Gaines, H., Gratton, C., Gross, K. L., Liere, H., Malmstrom, C. M., Meehan, T. D., Ruan, L., Robertson, B. A., Robertson, G. P., Schmidt, T. M., Schrotenboer, A. C., Teal, T. K., Wilson, J. K., and Landis, D. A. 2014. Perennial grasslands enhance biodiversity and 
multiple ecosystem services in bioenergy landscapes. Proc. Natl. Acad. Sci. U.S.A. 111:1652-1657.

Whitaker, B. K., Reynolds, H. L., and Clay, K. 2018. Foliar fungal endophyte communities are structured by environment but not host ecotype in Panicum virgatum (switchgrass). Ecology 99:2703-2711.

Wieder, W. R., Allison, S. D., Davidson, E. A., Georgiou, K., Hararuk, O., He, Y., Hopkins, F., Luo, Y., Smith, M. J., Sulman, B., Todd-Brown, K., Wang, Y.-P., Xia, J., and Xu, X. 2015. Explicitly representing soil microbial processes in Earth system models. Global Biogeochem. Cycles 29: 1782-1800.

Williamson, K. E., Fuhrmann, J. J., Wommack, K. E., and Radosevich, M. 2017. Viruses in soil ecosystems: An unknown quantity within an unexplored territory. Annu. Rev. Virol. 4:201-219.

Xia, Y., Amna, A., and Opiyo, S. O. 2018. The culturable endophytic fungal communities of switchgrass grown on a coal-mining site and their effects on plant growth. PLoS One 13:e0198994.

Xia, Y., Greissworth, E., Mucci, C., Williams, M. A., and De Bolt, S. 2013. Characterization of culturable bacterial endophytes of switchgrass (Panicum virgatum L.) and their capacity to influence plant growth. GCB Bioenergy 5 : 674-682.
Xue, C., Hao, Y., Pu, X., Ryan Penton, C., Wang, Q., Zhao, M., Zhang, B., Ran, W., Huang, Q., Shen, Q., and Tiedje, J. M. 2019. Effect of LSU and ITS genetic markers and reference databases on analyses of fungal communities. Biol. Fertil. Soils 55:79-88.

Yánez-Mendizábal, V., Viñas, I., Usall, J., Torres, R., Solsona, C., Abadias, M., and Teixidó, N. 2012. Formulation development of the biocontrol agent Bacillus subtilis strain CPA-8 by spray-drying. J. Appl. Microbiol. 112: 954-965.

Zalapa, J. E., Price, D. L., Kaeppler, S. M., Tobias, C. M., Okada, M., and Casler, M. D. 2011. Hierarchical classification of switchgrass genotypes using SSR and chloroplast sequences: Ecotypes, ploidies, gene pools, and cultivars. Theor. Appl. Genet. 122:805-817.

Zhang, B., Ryan Penton, C., Xue, C., Quensen, J. F., Roley, S. S., Guo, J., Garoutte, A., Zheng, T., and Tiedje, J. M. 2017. Soil depth and crop determinants of bacterial communities under ten biofuel cropping systems. Soil Biol. Biochem. 112:140-152.

Zhang, Y., Zalapa, J. E., Jakubowski, A. R., Price, D. L., Acharya, A., Wei, Y., Brummer, E. C., Kaeppler, S. M., and Casler, M. D. 2011. Post-glacial evolution of Panicum virgatum: Centers of diversity and gene pools revealed by SSR markers and cpDNA sequences. Genetica 139:933-948. 